University of Rhode Island

DigitalCommons@URI

Open Access Master's Theses

1979

\title{
The Extent of Exclusionary Zoning Practices in Washington County, Rhode Island
}

Thomas Bigelow Hooper

University of Rhode Island

Follow this and additional works at: https://digitalcommons.uri.edu/theses

\section{Recommended Citation}

Hooper, Thomas Bigelow, "The Extent of Exclusionary Zoning Practices in Washington County, Rhode Island" (1979). Open Access Master's Theses. Paper 622.

https://digitalcommons.uri.edu/theses/622

This Thesis is brought to you for free and open access by DigitalCommons@URI. It has been accepted for inclusion in Open Access Master's Theses by an authorized administrator of DigitalCommons@URI. For more information, please contact digitalcommons-group@uri.edu. 


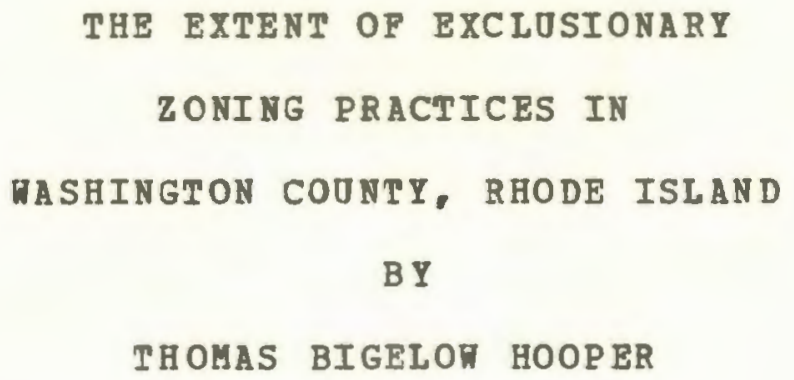




\section{MASTER OF COMMUNITY PLANNING THESIS PROJECT $\mathrm{OF}$}

THOMAS BIGELOW HOOPER

Approved:

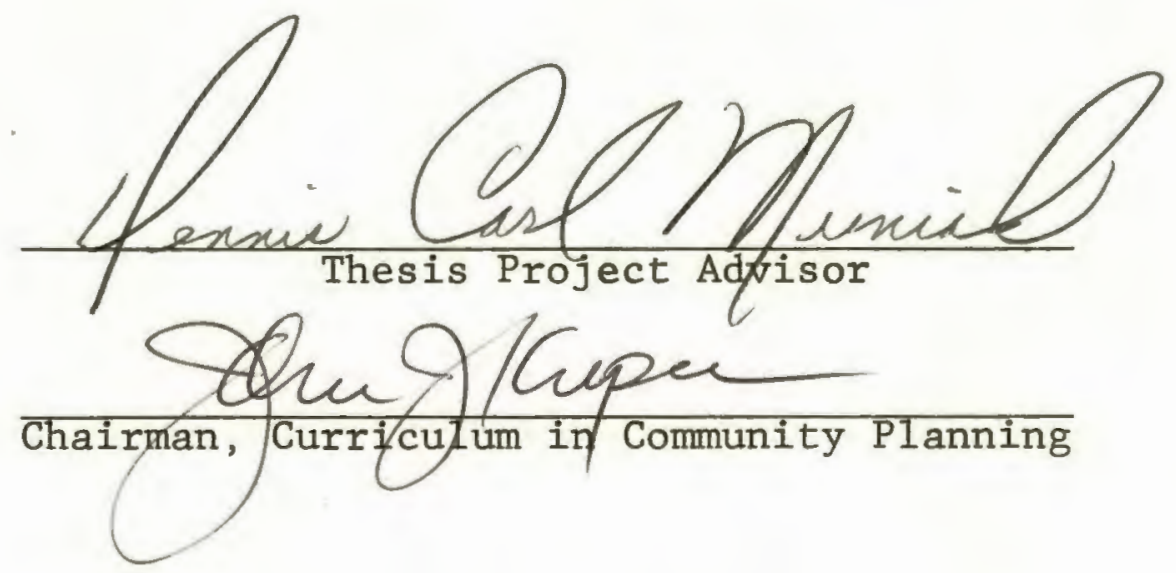

UNIVERSITY OF RHODE ISLAND

1979 


\section{ACKNOWLEDGHENTS}

I would like to thank my thesis project advisor, Dr. Dennis Muniak, who supplied the moral support and technical advise pertinent to this investigation. without Dr. Muniak's help and calming influence, it is doubtful that this profect could have been finished on time. I would also like to thank MI. Thomas E. Deller, Mr. Bruce D. Bender and "Harmon" for their invaluable help in preparing and printing this report. 
TABLE OF CONTENTS

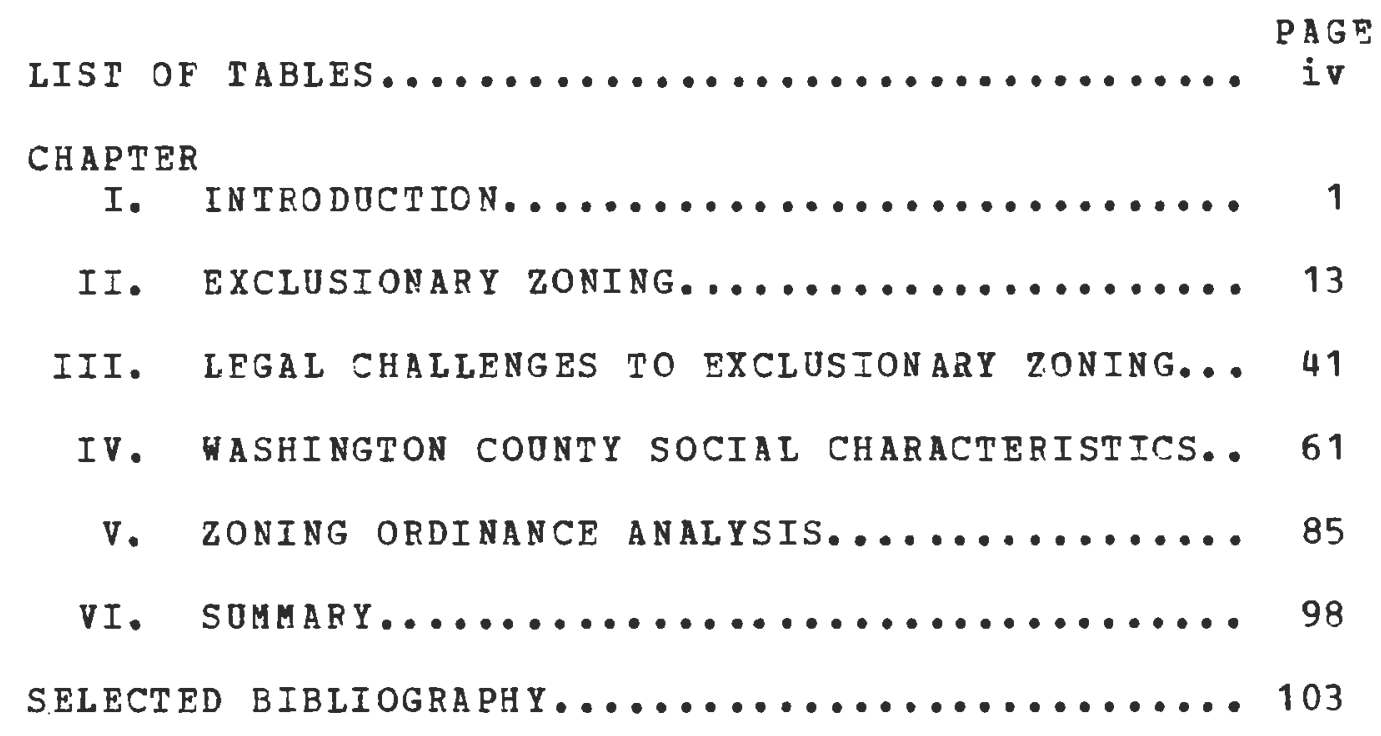


TABLE

I. AこCEPTABILITY OF VARIOUS HOUSTNG TYPES

PAGE TO SUBURBAN LEADERS IN NEW JERSEY . . . . . . 15

II. A WORKING DEFINITION OF EXCLUSIONARY ZONING 36

III. RHODE ISLAND POPULATION,1950-1975........ 64

IV. RHJDE ISIAND POPOLATION OF MAJOR CITIES... 65

V. FAMILIES NITH INCOMES BELOH THE POVERTY LEVEL.......................... 68

VI. MFDIAN FAMILY INCOME FOR WASHINGTON COONTY COMMUNITIES..................... 69

VII. DISIFIBUTION OF FAMILY INCOMES FOR WASHINGTON COUNTY COMMUNITIES-1959............... 71

VIII. DISTEIBUTION JF FAMILY INCOMES FOR VASHINGTON こOUNTY COMMUNITIES $-1970 \ldots \ldots \ldots \ldots \ldots \ldots \ldots \ldots . \ldots 72$

IX. DISTPIBUTION OF FAMILY INCOMES FOR VASHINGTON COUNTY COMMUNITIES, 1959-1970.......... 73

X. RHODE ISLAND EMPLOYMENT GRONTH,1960-1975... 75

XI. 1970 TOTAL HOUSING UNITS IN RHODE ISIAND... 76

XII. 1970 TOTAL HOUSING UNITS IN WASHINGTON COUNT............................... 77

XIII. MOBILE HOMES IN HASHINGTON COUNTY........ 79

XIV. EXISTENCE OF VARIOUS ZONING PROVISIONS IN WASHINGTON COUNTY.................... 88

XV. ZONING ORDINANCE ANALYSIS MATRIX FOR WASHINGTON COUNTI RHODE ISLAND.......... 90

XVI. FREQUENCY OF ZONING CHARACTERISTICS....... 91 
I. INTRODUCTION 
Discrimination in housing continues to impact all segments, institutions, and persons in our society. This discrimination exacts a heavy price from our economy. Educational opportunities, recreation, transportation and employment by excluding large segments of our population from utilizing them fully.

The problem of individual and systemic housing discrimiration is multi-faceted. It is influenzed by market inadequacies, policies of Federal, state and local governments, corporate entities, many aspects of the housing industry and the bohavior of public and private persons engaged in the real estate industry.

Perhaps the single most important element that impacts on all aspects of housing are the regulations and practices of zoning and planning commissions or boards.

Recently, the Washington county portion of Rhode Island was designated as an area which would exhibit major growth in the near future. This statement by the Rhode Island office of statewide planning, only served to reinforce what many communities in rashington County had feared would happen.1 To towns in the area currently under severe development pressures, such as Pichmond and Exeter. this came as no surprise.

With such projected growth on the horizon, this study will look at the capabilities of the nine communities in Washington county to provide for this added population through their zoning practices.

This study is concerned with the question of whether 
zoning practices in the southern part of Rhode Island could be interpreted as discriminating against classes of population legally protected from such abuse. To determine whether a community is acting in an "exclusionary way," it is necessary to understand both the content of the zoning requlations and the social characteristics of the community.

The purpose of this study is to identify the extent to which communities throughout the Washington County area have, or have not, adopted zoning regulations that restrict the nature of housing opportunities for residents of the area. The study will assume that within every comunity there should exist either available housing for low-and moderate-income households, or the possibility of developing such housing.

In examining the county and the particular communities within it, to determine the availability of housing choice for lower income and other minority households, it is necessary to examine the zoning regulations in relation to the social characteristics of the community.

Two basic questions will be dealt with: (1) Do the zoning provisions preclude the construction of lower cost housing? and, (2) How do the characteristics of the comunity reflect the effect of these provisions?

understanding the type of housing that can be
construated within the community, under present zoning


restrictions, helps to identify the effect of those restrictions on the ability of low-and moderate-income households to move into the community. onderstanding who currently lives within the community and the kind of housing opportunities that are presently available, can be used as an indication of the degree to which that community has responded to the housing needs of the state.

In the last ten years there has been a great deal of attention at the national level to zoning as a derics to restrict low- and moderate-income households seeking affordable housing in suburban areas. In 1968, the National Commission on Urban Problems (the Douglas Commission) reported that "zoning was intended to control land development, hut fiscal considerations often distort it, leading to economic and racial exclusion." The Commission's report goes on to say:

The most serious effect of fiscal zoning is the spate of exclusionary practices relating to residential development. The aim, of course, is to keep out lower income groups, and especially large families which require siqnificant public expenditures in education, public health and welfare, open space, Iecreational facilities, police and fire, and the like... usually nobody bothers to ask where the families who are being excluded should live. 2 
Th $\cong$ Comission sumarized land use regulations from a national perspective. It stated that:

The central problem of land-use regulation today is how to achieve the ambitious objections of these regulations without, in the process, sacrificing other essential public objectives. of great concern to the commission is how to achieve th $\equiv$ legitimate objectives without misuse of the rules to raise housing costs. 3

Since the Douqlas Comission reported its findings in 1968, federal housing subsidy programs, for the first time, provided mechanisms for developing increased numbers of privately sponsored housing for lower income households in suburban areas. Many of these programs encountered barriers in some suburban commuities such as requirements of larqe lots or prohibition of multi-family units. As a consequence, courts in Pennsylvania, New Jersey and New York were faced with challenges to overly restrictive zoning regulations. One of the landmark decisions wherein municipal land-use regulations vere challenged is the case

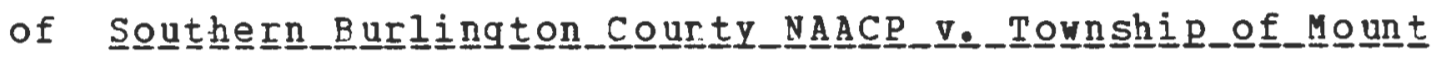
Laurele - In 1975, the high court of New Jersey held that municipal land-use regulations must serve both the needs of the residents of Mount Laurel and the general velfare of the population contained within the metropolitan area in Which Mount Laurel is located. The court held that: 
We corclude that every such municipality must, by its land use requlations, presumptively make realistically possible an appropriate variety and

choice of housing. More specifically. presumptively it cannot foreclose the opportunity of the classes of people mentioned for low and moderate income housing and in its regulations must affirmatively afford that opportunity, at least to the extent of the municipality's fair share of the present and prospective regional need. Therefore, these obligations must be met unless the particular municipality can sustain the heavy burden of demonstrating peculiar circumstances which diztate it should not be required so to do.4

This national report and court cases in Pennsylvania, New Jersey and New York are additional reasons why this investigation of local zoning regulations is being undertaken in Washington county at this time. The issue is not new and certainly is not unique to southern Rhode Island.

zoring is a device which aims to define the locations in a community in which different classes of activity may take place and the intensity of development of that activity. Zoning, for the most part, has been found to be an admirable ard effective means of preventing activities in a community which may be injurious to other classes of activities from occupying the space in the same general district or zone. Thus, activities tending to emit noxious products, e.g., noise, odor, smoke, or to induce heary truck traffic are kept apart from residential areas. The separation of disharmonious activities from one another is a social recessity in an urbanized society. 
Also, zoning is a technique of requlation of land development. It is a public action supported by the general objectives of the state's enforcement powers, its police power. Almost every jurisdiction in the state of Rhode Island has chosen to employ the powers delegated to them by the state to establish zoning regulations.

It is important to observe that both the state laws enabiinq towns to zone and the community laws are, of course, subject to the general rules of law established in both Rhode Island and United States Constitutions. With refererce to this particular study, the Due Process and Equal Protection clauses of the constitution are most important. It is the underlying hypothesis of this study that zoning, as practiced by some of the communities in Mashington county and by the state as initiator of local zoning power, may deny fundamental rights of legal protection to individuals discriminated against.

This is an investigation of zoning practices in Washington county. The study will examine two sets of related data: (1) The zoning ordinances of each of the communities comprising washington county, i.e., Charlestown, Exeter, Hopkinton, Narragansett, New Shoreham, North Kingstown, Richmond, South Kingstown and Hesterly; and, (2) The selected social characteristics of the nine communities involved. 5 
Some of the additional detailed analysis that would be required in order to make a causal determination of exclusionary zoning practices in a particular community are the examination of the administration of the zoning ordinance, and of related land-use practices in addition to the zoning regulations themselves. Some of these regulations, known to increase the cost of land and housing. are practices of Inland and Coastal Vetlands Commissions, and conservation Commissions. Their actions may exacerbate the impact of a town's restrictive zoning practices, or in combination with local zoning, may create exclusionary policies not in the zoning ordinance themselves.

other regulations and policies that may add to a community's ability to place housing prices out of the reach of low- and moderate-income families are subdivision regulations, building codes, and provision or withholding of water and sewer lines.

Unfortunately, just looking at a commity's zoning requlation will not enable an individual to concretely state that there is, or is not, housing discrimination taking place. Housirg discrimination is a systemic condition. Systemic housing discrimination is defined as "a subtle and complex form of discrimination which is manifest in the policies, patterns or practices of systems or institutions." 6 such policies, patterns or practices often have the effect of excluding whole segments of 
society from availing themselves of equal opportunities.

This study will be comprised of four main components. First, it will review the literature dealing with zoning, exclusionary zoning and grouth controls. From this background information, a working definition of exclusionary zoning practices will be formulated for the purpose of this investigation. This working definition will contain current techniques of exclusionary zoning which are being practiced by municipalities.

Also, the effect of zoring regulations on the zost of housing will be explored and conclusions drawn relevent to this study will be stated.

The next component of this investigation will deal with the many legal challenges to exclusionary zoning practices. A brief look into the legal aspects of exclusionary tactics practiced by municipalities is required to acquaint us with the current position taken by both the federal and state court systems.

Thirdly, the social characteristics of Nashington County and its member communities will be examined. To place this information into the proper perspective, the social characteristics examined in Hashington Courty will be compared to the state of Rhode Island as a whole. By making this comparison, information obtained for the commities under study and the state can be evaluated 
showing both similarities and differences that are required to determine the extent of discrimination in Washington County.

The final, major component of this investigation will deal with the zoning ordinance analysis itself. Each of the nine community's zoning regulations will be examined for exclusionary practices. Two aspects of the zoning ordinance itself are important: Requirements within the zoning ordinance governing the type of residential unit and standards which control the characteristics of that development; and requirements within the zoning ordinance which identify the administrative requirements for approval of residential development.

A summary analysis and conclusions will complete this investiqation. While positive causal relationships between zoning practices and discriminatory consequences are not quaranteed, probable cause will be given, if warranted, to link such findings.

For many citizens of Rhode Island, the land use pattern created by the growth and development of cities and towns guided by local zoning ordinances, has been extremely beneficial. Many residents are able to find good housing in pleasant residential communities, served by excellent public schools and recreational facilities, within reasonable commuting distance of their places of work. Many observers contend, however, that the benefits of this land use pattern have not been available to everyone. 
This is particularly true for members of racial minority groups, households with female heads, and persons of lowand moderate-income. It is claimed that the preservation of larqe parts of metropolitan areas, almost exclusively for single-family homes on large lots, has meant an enforced scarcity of housing within those communities. These suburban commities have benefited most from tho suburban surge in office and industrial growth, and now enjoy the relative advantages of good public education and other community services.

This land development pattern, and the resulting pattern of housing arailability, has strengthened the forces maintaining older central cities as the place of residence of the overwhelming majority of racial minority groups and the bulk of 1 ow- and moderate-income persons and female-headed households.

The reliance on zoning to achieve certain objectives has resulted in a land development system in which relatively high income is required as a condition for obtaining access to a commity. It is this outcome of zoning, that of economic exclusion, which is under fire presently. Although this study will only investigate the Washington county area of the state, it is hoped that interest in the subject can be raised to promote additional efforts on a statewide basis. 
1. Rhode Island Statowide Planning Program,

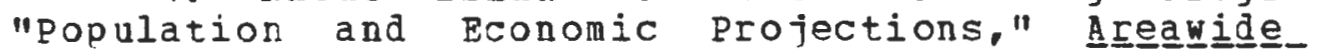

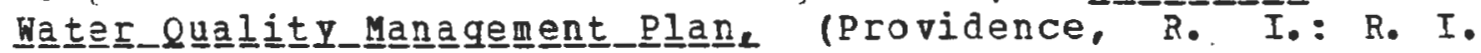
Statewile Planning Program, July, 1977).

2. The National zommission on Urban Problems (The

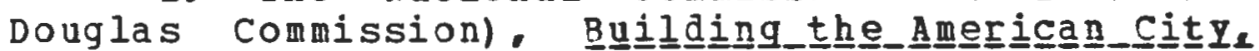

(Washington, D. C.: Government Printing office, 1968). p. 18 .

3. I $\underline{\text { id }}$., $\mathrm{p} .208$.

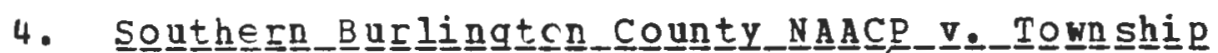

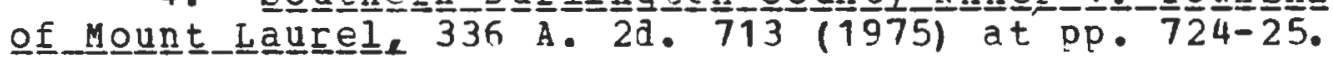

5. New Shoreham prior to 1963 was contained in Newport County.

6. State of Connecticut Commission on Human Rights

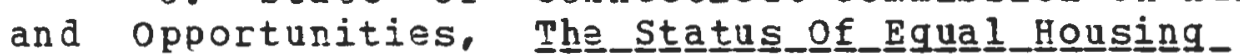

opportiunityl (Hartfor d, Conn.: Commission on Human Rights and opportunities, 1978), p. XVI. 
II. EXCLUSIONARY ZONING 
This section deals with the concepts of zoning, exclusionary zoning, growth control techniques and the effect of zoning on the cost of housing. Also within this section, a working definition of exclusionary zoning will be formulated for the zoning ordinance analysis phase of this investigation. Besiles the formulation of a working definition and the review of the effect of zoning on the cost of housing, the primary purpose of this section is to acquaint the reader with the concepts of exclusionary zoning and growth control.

First, the concept of zoning and some of its problems will be reviewed followed by exclusionary zoning and growth control techniques. Next, the effect of zoning practices on the cost of housing will be discussed.

From this review, a working definition of exclusionary techniques will be assembled.

Zorirg is a "legislative action, usually on the municipal level, which separates or divides municipalities into districts for the purpose of regulating, controlling, or in some way limiting the use of the property, and the construction and/or structural nature of buildings erected within the zones or districts established."1

zoning and building codes are inherently exclusionary. Their purpose is to exclude land uses deemed 
inappropriate by a local jurisdiction. Regardless of the intent of local restrictions, they inevitably restrict housing opportunities.

Zoning is based on the police power of a governmenta 1 unit. As such, its specific aim is to protect the public's health and safety. More generally, zoning is supposed to promote the general welfare and foster rational patterns of development.

Much of what is printed in the metropolitan and suburban newspapers about land-use activity in outlying residential areas revolves around zoning. Hith the adoption of a zoning ordinance, the particular government will apply certain sections of the ordinance to the land area within its boundaries. This is conducted on the basis of the public official's understanding of the needs and feelings of the community.

zoning is essentially a middle- and uppermiddle-class matter. Further, zoning traditionally has been a homeowner's matter. zoning is considered by the homeowner to be the primary means by which he/she can protect his/her residence, neighborhood, and home investment. of course, not all homeowners see zoning in this light, but enough do to cause this view to be translated into political action.

What are we protecting the single-family residence from? The answer appears to be that we are protecting it from virtually any land use that the most vocal of the 
single-family residents do not consider desirable. In some cases this may include even single-family units! Table I identifies the "feelings" of suburban leaders in New Jersey to various residential forms of development.

\section{T므므트프}

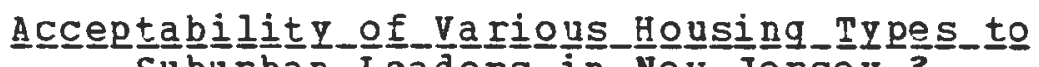

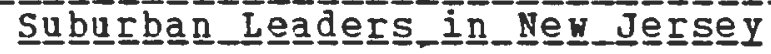

\begin{tabular}{|c|c|c|}
\hline 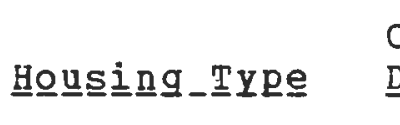 & Considered & $\begin{array}{l}\text { Considered } \\
\text { Undesingable }\end{array}$ \\
\hline Single-family, & & \\
\hline $\begin{array}{l}\text { large lot } \\
\text { Single-family. }\end{array}$ & 79 & 20 \\
\hline small lot & 49 & 48 \\
\hline $\begin{array}{l}\text { Garden Apartment } \\
\text { High-rise }\end{array}$ & 46 & 52 \\
\hline Apartmeat & 27 & 70 \\
\hline Mobile Home & 9 & 91 \\
\hline
\end{tabular}

Besides these residential land-uses considered above, other undesirable land-uses include: industrial uses (especially); most, if not all, commercial uses; residential uses for the elderly; perhaps townhouse units, and certair forms of public uses and facilities.

Perhaps the most dreaded land-use of all, are homes for low-income individuals or families with incomes lower than those of the present residents.

Already in our discussion of zoning we have come 
across the imposition of an individual's values into the zoning process. This intertwining of values and practice has lea to many of the current techniques of exclusionary practices which will be discussed later.

This inherent difficulty, the intertwining of values and zoning practices, has fostered many anti-zoning writings. One author of such anti-zoning literature believes that "nonzoning" is just as effective, if not more effective, in facilitating urban growth as present zoning is. 3 Bernard Siegan feels that economic forces tent to make for a separation of uses even without zoning. Even when the economic forces do not guarantee that there will be a separation, and separation is vital to maximize values or promote tastes and desires, property owners will enter into agreements to provide such protection. Restrictive covenants covering home and industrial subdivisions are the most prominent example of this, although they are not always legal.

In his studies, siegan found that a nonzoned city, such as Houston, Texas, is a "cosmopolitan collection of propertp uses." The standard is supply and derand, and if there is economic justification for the use, it (the land-usel is likely to be forthcoming.

Sieqan feels that zoning restricts the supply of some uses, and thereby prevents some demands from being satisfied. It may likewise impede innovation.

In general, however, zoning in the major cities, 
which to contain diverse life styles, probably has responded and accommodated to most consumer demands. mhis response has generaly not occurred in the more homogenous suburbs.

Most of the developed residential areas of the outlying sections of this country's metropolitan areas are zoned for small-lot uses, that is, single-family residences on lanù parcels of less than a quarter acre each. This accounts for the dominant characteristic of the contemporary middle- and upper-income residential areas in metropolitan regions, the single-family residence on a small lot. These small-lot homeowners have traditionally supplied the political power behind currert suburban zoning policies. But over the past fifteen years or so, these suburban residents have not been satisfied to provide newcomers with the same kind of small lots that the old residents have and, instead, have voiced their support for zoning in the larger-lot categories (one acre or mora).

The reasons for this are undoubtedly mixed, but one of the most important has been the desire to keep currently nonurbanized land in an essentially undeveloped state.

Zoning, as currently practiced, does not encourage diversity, variety, or experimentation. It does not provide us with the amenities and the wide range of land uses that many of us desire. In fact, zoning seems to be especially well-designed to assure the misuse of land. Current zoning has the effect of creating a sameness and a 
routine monotcmy in many parts of our urban environment. The current practices in zoning have evolved with only slight, if any, periodic re-evaluation. "He are victims of the status quo in zoning, as change is not automatically guaranteed in land-use controls any more than in any other policy field." The tendency appears to be for parochialism to maintain control, for narrow values to prevail, and in some cases, for outright oppression to go unchallenged.

One of the most conspicuous failures of suburban zoning ordinances can be seen in the endless rows of look-alike houses constructed across the landscape.

Just what is zoning? Zoning was originally widely regarded as constituting a reformed view of nuisance law, and as having similar purposes. As such, like the nuisarce law, it was viewed as a legitimate exercise of the police powers of the state. Zoning had to have its legal basis in the police power because it placed substantial new restrictions on the use of personal property.

Nuisance law and early zoning ordinances had the common aim of protecting the neighborhood. In practice, if not in early statements of zoning theory, one of the purposes of zoning has been to protect neighborhoods from uses that threatened in some way to reduce the quality of the area. In many cases, this understanding of the purpose 
of zoning has been described as intending to prevent the reduction of overall property value of a neighborhood by excluding a particular use. As the Douglas commission phrased it in 1968: "The purpose of zoning becomes, in effect, to keep anyone from doing something on his lot that would make the neighborhood a less enjoyable place to live or make a buyer less willing to bur."s

Given individual property-owner incentives, neighborhoods of noticeably higher "quality", whether based on dersity or other factors, would tend to attract new residents until their "quality" was reduced to the average. The means of dealing with this critical problem is, of course, land-use regulation. Zoning ordinances establish minimum lot size, floor space, lot frontage, setback distance, side and rear yard size, and other similar minimum quality standards for each district.

since the rapid spread of zoning in the 1920s, its method of neighborhood or community protection has changed little. Undesired land-use categories are excluded from an area, and many changes in existing non-conforming structures are also controlled. The rigidity of zoning classifications has made it almost impossible to admit individual desired uses if they belong to the wrong category. Was this rigidity intended by the early pioneers of zoning or has it evolved due to vested interests?

It is obvious to most observers of the urban environment that the original nature of the zoning process 
has been completely turned around. According to Daniel Mandelker, zoning was (and is) a qross tool at best. As a result, zoning was gradually converted from a system which preregulated land uses to a system of administrative control ir which individual applications for development were considered ad hoc as applications for rezoning of various kinds came before zoning officals.6

These changes in the purpose of zoning largely came about with changes in methods of land development. rhile earlier development took place piecemeal, and on small lots, changes in building methods stimulated by greater accessibility induced by the automobile, led to development of larqe tracts of land especially assembled for development purposes. The large subdivision, or apartment complex, replaced the single home on individual lots. Where these massive developments would go became the important zoning problem. No longer could the exercise of zoning controls be justified in the name of preventing land-use conflicts. Zoning has become a method of implementing larger objectives based on a comprehensive plan.

With this background information in mind, we can now turn to the impact of presont-day zoning practices on problems of facilitating metropolitan development.

Although the discriminatory consequences of municipal 
zoning have received hroad public attention only in recent years, they have had a long history and have occasionzlly

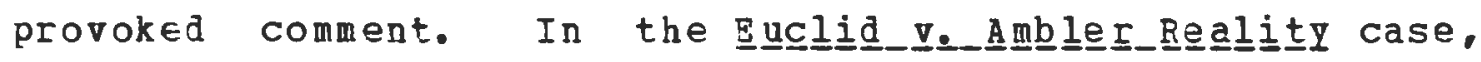
which established the constitutionality of zoning, the federal district judge who first heard the case perceived the purpose of Euclid's zoning as Exclusionary and found it un acceptable. 7

Zoning orlinances, through the substance of their requlation or in their administration, are said to be "exclusionary" if they tend to exclude low-income individuals or minority racial groups. How this exclusion is accomplished depends upon the particular technique used. some zoning ordinances may prohibit certain forms of residertial units outright, such as multi-family apartments or mobile homes, or they may be more sophisticated. Por example, a community may provide in their zoning ordinance a procedure through wich administrative relief may be granted, but no such relief is ever made. Other results of zoning controls included in this inspection are density requirements. Many times large sections in developing suburban communities will be zoned at very low densities. These jensities are much too low for moderately priced housing, not to speak of low cost units. In other cases, unreasonable minimums are placed on house sizes, or apartment areas are limited to projects with only one-bedroom units, thereby excluding families with children. 
Quite clearly, exclusionary zoning practices are a barrier to the effective implementation of a housing program for lower income families in suburban areas. Until recently, this was the only perceived consequence of exclusionary zoning practices. As of late, the difficulties of moderate- and even upper-income families in obtaining homes in the suburbs have come to pass. The price of new, single-family construction alone, unaffected by large-lot zoning, acts as a natural eccnomic barrier to low-income households. The results of both low- and moderate-income households being barred from entering the new housing market is that both groups must occupy ard compete, unevenly, for the only housing they can afford -the older, single-family and multi-family units. These older units tend to be located in the central cities and in older, close-by suburbs.

As stated previously, each regulation within the zoning ordinance which affects the development of land for residential use or wich affects the construction of residential dwelling units, and wich is not reasonably necessary to protect the health, safety, morals, and general velfare of the public, could be labelled restrictive. This is particularly true if the ordinance has the effect of excluding different types of dwelling units or escalating the costs of constructing housing units. The most commonly used exclusionary practices have been identified and documented in various studies and 
reports. The most common of these techniques uill be discussed now.

Mary communities require that new buildings be constructed with a minimum amount of floor space. Naturally, the larger the required size of the dwellina unit, the more expensive it will be to construct. oriqinally established to protect the health and safety of the resident, they need be no larger than minimum settings of standard codes and many times do not vary for different types of dwelling units. The potential escalating effect on home costs by using minimum floor area requirements was highlighted by the Douglas Commission, which stated that minimum floor areas "raise the lower limit of construction costs, and thus can be the most direct and effective exclusionary tool." 8 That same commision concluded that almost half of the bodies of government on a national level had zoning ordinances which required a minimum floor area for single family houses. Municipalities in rapidly growing states almost universally zone for minimum building floor area.

Minimum floor area requirements are not, per se, exclusionary. These requirements are frequently dictated by health standards. When the minimum standards of health are qrossly exceeded, the Exclusionary label can be fairly applied. In many instances, the zoned minimum floor area requirements far exceed those required for health reasons and are out of line with current energy conservation 
policies.

Many communities specify the minimum lot size on which housing can be constructed. This is a comon and rather popular technique used in restricting individuals from residing in a particular commity. These minimum lot sizes are frequently quite large. Large-lot zoning has often been condemned as an exclusionary zoning practice in that required lot sizes are not justifiable, in $\in$ very case, from the standpoint of health, ecology, or aesthetics. critics charge that large lot sizes are mandated in order to raise the price of housing to a level affordable only to middle- or higher-income families.

Large-lot zonina, usually defined as any minimum lot size over one-half acre per unit, increases the cost of housing in several ways: it increases the cost of land per unit by reducing the total amount of housing that can be accommodated; it increases the home size most developers will produce on the parcel; it increases site development costs through the large linear feet of streets, sidewalks, curbs, sewer and water lines required for each lot; and by decreasing the number of homes that can be built in a community.

Excessive yard requirements also have the same effect as large-lot requirements. Front, side and rear yard set backs, as well as frontage requirements, tend to accomplish the same task, yet not as blatantly as large-lot requi $r \in \mathbb{m} \in \mathrm{n} t \mathrm{~s}$. 
Many communities also try to regulate the number of bedrooms per dwelling unit. Bedroom restrictions may not increase the the cost of the dwelling unit, except to the extent that they increase the demand, and, therefore, the price of larger units.

Bedroom restrictions usually attempt to limit the number of bedrooms permitted in dwelling units. They are primarily fiscal regulations designed to regulate the number of children that would require school facilities and have the effect of restricting the availability of units to large households.

The exclusion of mobile homes is a very popular practice among suburban communities. Many zoning ordinances do not permit mobile homes, or allow them only in undesirable rural or industrial areas. Many times they are permitted only as temporary uses rather than permenant dwelling units.

Mobile homes can also be excluded in indirect ways by imposing minimums related to floor area, lot size, or other factors which mobile homes cannot reasonably meet. Because mobile homes tend to be less expensive units, their exclusion is another way of restricting the housing possibilities for low- and moderate-income households.

\section{Many zoning ordinances restrict the type of} residential dwelling permitted to single-family, detached dwelling units. This effectively excludes any type of multi-family unit, such as townhouses, row houses, garden 
apartments, duplexes, or Planned Unit Developments and cluster developments. Because these typos of dwelling units are generally considered to be less expensive to construct and occupy, exclusion of these dwelling units will generally exclude low- and moderate-income households from the community.

cf the various zoning controls employed by suburbs which airectly affect population distribution, the most effective is prohibition of multiple-family dwellings. Large numbers of suburban commities ban apartments completely. Almost all zoning ordinances consizer apartments an inferior and, therefore, a more restricted land-use than single-family residences.

With apartments, suburbanites believe will come traffic problems, intensified demands on local schools and public services, increased taxes, and other unwanted changes. Successful efforts to restrict apartments take a number of forms. The most absolute, effective, and widespread curb is the lack of a provision in the local zoning ordinance for apartments. Prohibitions of limited duration (or moratoriums) also have become increasingly popular. Such pauses in development are said to permit the local qovernment to determine the impact of apartments on public services. Until these determinations are made, buildinq permits for apartments are not issued, regardless of the provisions of the local zoning ordinance. Communities which have sanctioned apartments in the 
past can prevent future construction by limiting multi-family housing to a fixed percentage of the total dwelling units in the local jurisdiction. once the quota is established, no further apartment development is permitted, even though vacant land may be zoned for apartments.

The remaining techniques, although they are not universally employed, do tend to restrict the availability of diversified housing in a community.

One of these is the use of design and improvement requirements. These regulations may represent unnecessary requirements to protect the health and safety of the resident, and in doing so will tend to increase the zost of housing unnecessarily. These items are better left to the discretion of households who can choose to add such improvements when they desire or can afford them. Examples of these requirements are: architectural controls, required garages, brick veneer, high fences or walls, extensive landscaping, and off street parking areas.

The final concept that will be discussed relating to exclusionary zoning devices also may be fulfilled through subdivision requirements. This last practice deals with site development requirements. The question of whether these rægulations are either necessary or justified in that they require exactions from developers is unresolved. In no instance does only the developer bear such costs, as all aditional costs are passed on to the future homeowner or 
renter. Both the number and cost of these reguirements have greatly increased over the last decade. Examples of these reguirements are: grading and landscaping provisions, street requirements and road specifications, street lighting, sidewalks and curbing, sewers and drainage facilities, garages, accessory storage buildings, and the extension of utility services to the subdivision site.

While these requirements may not be totally contained within the zoning ordinance, many times the combination of zoning and subivision requirements can account for these exactions.

Besides the openly exclusive reasons for enacting anyone of the previously discussed regulations, many communities adopt some of these requirements for other reasons. To stem even larger increases in property taxes, communities have often enacted large-lot and other admittedly exclusionary controls in the belief that such controls would restrain municipal expenditures and would insure that projected housing units would yield property taxes at least equal to the municipal expenditures they would incur. Many communty officials believe that houses built on large lots require fower and cheaper municipal services than multi-family and other comparatively high-density residantial developments. Large-lot homes. for example, often rely on septic tanks, precluding the need for municipal construction of costly treatment plants. Many local officials are persuaded that expensive. 
single-family homes built on large lots, are good "ratables"-- yielding more property tax revenue than the community expenditure they incur.

Communities practicing exclusionary zoning often defend their actions on the grounds of aesthetic and environmental considerations. 9 suburban officials in such communities frequently assert that their major concern is to preserve the rural character of the area by retaining large open space and by reducing traffic. Their exclusion of multi-family housing is often justified on aesthetic, as well as fiscal reasons; they maintain that such high-rise housing will cut off light and air and will increase traffic congestion.

The topography of some communities necessitates their strict limitation on the density of development in order to prevent dangerous flooding and sewer system bazkup conditions. Municipal officials in such communities have often enacted zoning statutes which in effect may be exclusionary but which are defended on the grounds of environmental protection. "From the negative of exclusion. it became the positive of environmental protection" as communties faced challenges to their zoning practices.10 Community officials often believe that land zoned for moderate-income housing, e.g., multi-family housing. depresses the value of adjacent properties. Conversely. they believe that exclusionary zoning, by limiting housing construction to high-priced units raises the value of both 
the property and its adjacent land.

fecently, communities have adopted some or all of the exclusionary practices in an attempt to "control" the growth within their boundaries. As communities begin to struggle with the problems attendant upon an increasingly rapid rate of growth, their first responso is often to increase lot size requirements in their zoning ordinances.

Many communities react to rapid growth by restricting development to single-family homes on lots ranging from one to six or more acres. This restriction, which is often used in conjunction with other density-limiting devices such as minimum floor-area requirements, is most often imposed in outlying fringe areas that are either undeveloped or just beginning to show serious developmental pressures.

It is important to distinguish two differing applications of the large-lot zoning concept. First, it may be used as a temporary barrier to intensive residential development, establishing what in effect are holding zones. The second use of the tool involves the community actively planning to have only low-density residential development as the ultimate use of the land so zoned.

It is often very difficult to ascertain whether a particular ordinance is intended to enact temporary or permanent large-lot zoning, because few make such a distinction on their face. However, the distinction is crucial because each type of zoning implies objectives that 
are entirely distinct from those of the other.

The use of large-lot zoning as a temporary bar to residential consiruction is a direct attempt by the community to control the timing of urban तevelopment. With this approach, intensive residential construction is not entirely prohibited; rather, it is postponed until the municipality can accommodate it.

The holding zone concept has several primary uses. First, it can be used to prevent development from taking place in those areas which are as yet inadequately served by public facilities such as water and sewer lines, roads, schools, and recreational facilities. second, the holding zone is also effective as an interim control device, pending the adoption of permanent zoning reguirements. Finally, communities may establish holding zones to provide that all development proposals will come under their IEview.

In addition to its temporary use, large-lot zoning can be used to establish the permanent character of the undeveloped land. The belief in many municipalities is that it can be used to prohibit construction which would otherwise encroach upon prime adricultural land or other valuable open space. It can also be used to protect environmentally sensitive areas.

In addition to these protective objectives, residents of non-urban areas may wish to preserve the character of their community. Further, such growth control techniques 
may be imposed for fiscal reasons. Finally, since explicit racial and social exclusion is illegal, some communities seek to price out "undesirables" with large-lot zoning techniques.

By placing much of a community's vacant land in large-lot zones, premature resiaential development can be forestalled. However, this action allows no flexibility for meeting future changes in a town's needs. Furthermore, zoning all vacant land in the same way forecloses a responsiveress to differing pressures. For this reason. when a high percentage of the vacant land is placed into large-lot zones, the political pressure for individual rezonings can be overwhelming.

Finally, it should be noted that the rate of growth is not necessarily slowed by increasing lot sizes. Increasing lot sizes may in fact sometimes have the opposite effect, making the area more attractive to potential homebuyers.

Large-lot zoning requires development to be of very low density. A rural appearance will not necessarily result from large-lot zoning. Development of single-family homes on one-acre lots often produces uniform, unpleasing tract subdivisions. Large-lot zoning can al so consume land at an extremely rapid rate.

If large-lot zoning is adopted only as a temporary bar to development, there can be fiscal savings for the community without serious adverse economic impacts for the 
residents. Such a strategr, by limiting premature residential construction, allows the community to phase the provision of services in the most rational manner. Since hiqher densities will be allowed only as services are provided, the adverse economic impacts on individual residents are minimized. In fact, the residents may well benefit, because the increased fiscal stability of local governments and the rational provision of urban services may lead to lower tax rates.

Iong-term fiscal savings for local governments that enact large-lot ordinances are uncertain at best. Ihe per capita cost of providing services may even be higher. With large-lot development, some urban services, such as mass transit and water and sewer systems, become inefficient and quite costly.

While the position taken by the courts is relatively clear in respect to exclusionary practices by communities, leqitimate growth control policies have not been adequately tested. Growth control policies may be the prime land-use question of the 1980s, as more and more communities aropt such practices.

Many land-use regulations affect the cost of housing and may make it more expensive to construct housing. The Iesult is that much of the available housing is beyond the 
economic reach of most low- and moderate-income households. zoning regulations are one of a large number of factors influenzing housing costs. Regulations affect the type of unit that can be constructed; they influence the price of land; they influence the price of the housing unit; and they affect the time it takes to develop such housing and may, therefore, add to the cost.

$$
\text { Regulations within the zoning ordinance affect the }
$$

availability of housing at costs affordable by low- and moderate-income households in many ways. Most of these fall within one of the following four areas:

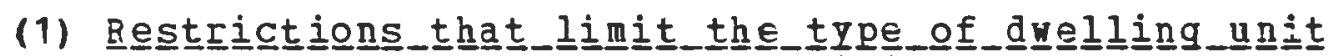
permitted. These regulations limit the possibility of constructing multi-family units or mobile homes. These housing types can be provided at less expensive costs than single-family units. Eliminating the possibility of providing these types of units lessons the chances that housing will be made available at lower costs.

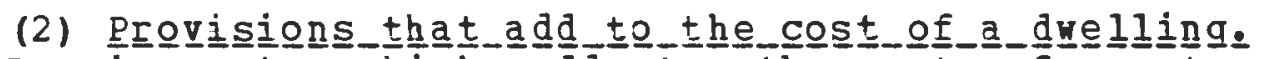
Requirements which add to the costs of construction are those provisions which are in excess of those required to protect the health, safety and welfare of the public. Removing these regulations allows for housing to be constructea at lower costs but does not prevent individual homeowners from adding to the basis requirements in the construction of their own home when they can afford to.

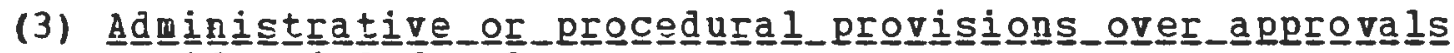

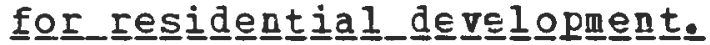

These provisions discourage developers from proposing certair types of developments and may involve sufficient approval time to add to the cost of the unit.

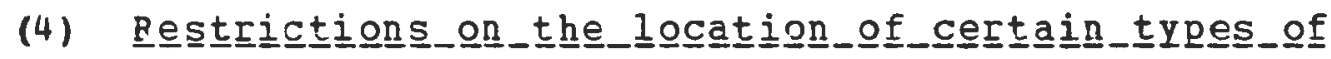




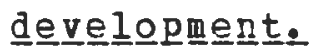

Zoning ordinances regulate where development can take place as well as what kind is allowed. The amount of land and the location of that land will affect the cost of that housing unit. When building lots are scarce and expensive, a developer tends to build more expensive houses so that the land price is not an unreasonably high proportion of the total price of the house and lot. 11

If zoning is not always the most critical element in determining land price as some have stated, it is certainly a most important factor. Virtually all regulations affect the cost of constructing a housing unit. However, the purpose of this chapter was to make reasonable judgments which can be used to identify regulations which may be present that foster the increasing cost of housing units.

From the background readings on zoning, exclusionary zoning, and growth control techniques, the following ten indicators have been chosen to comprise our working definition of exclusionary zoning. The following items were selected as the fairest and best indication of the extent to which the zoning provisions escalated the zost of housing and prevented the construction of types of housing units that may be provided at lower cost. 
$\underline{\underline{T}} \underline{\underline{A}} \underline{B} \underline{\underline{E}} \underline{\underline{E}}-\underline{I} \underline{\underline{I}}$

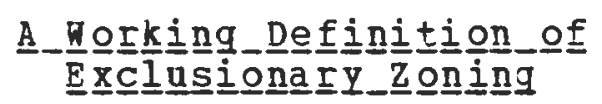

(1) Those zoning ordinances which provide a minimum lot size for single-family dwelling units of 20,000 square feet (one-quarter acre) or more.12

(2) Those zoning ordinances which provide a minimum floor area size for single-family dwelling units of 1.000 square feet or more.13

(3) Those zoning ordinances that prohibit the construction of multi-family dwelling units. (Multi-family is defined as dwellings with three or more household units).

(4) Those zoning ordinances that permit the construction of multi-family units only through special provisions, such as special permits or site plan review.

(5) Those zoning ordinances that permit the construction of multi-family units but limit the nature of those units through bedroom restrictions.

(6) Those zoning ordinances that permit the construction of multi-family dwelling units only at densities of less than five dwelling units per acre or more than 8,000 square feet per dwelling unit.

(7) Those zoning ordinances that totally prohibit mobile homes.

Zoning ordinances will also be identified which provide for types of residential construction that may be provided at lower cost. The following items were selected for their tendency to provide lower cost housing: 
(8) Those zoning ordinances which provide a minimum lot size for single-family units of 8,000 square feet or less.

(9) Those zoning ordinances that permit multi-family dwellings to be constructed as a right and allow for densities of six dwelling units per acre or less than 8,000 square feet per unit, and do not use bedroom restrictions.

(10) Those zoning ordinances that permit the provisior of mobile homes or mobile home parks.

These ten elements will be used later in the zoning ordinanze analysis phase of this study.

It was the intent of this section to lay the foundation of our investigation by reviewing the concepts of zoning, exclusionary zoning and growth control techniques. From this review, a list of exclusionary requirements as well as possible incentives to lower the cost of housing has been assembled for use in the focal point of this investigation. 


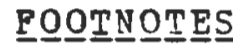

1. Steven H. Gifis, Law Dictiongary (Woodbury, New York: Barron's Eaucational Series, Inc., 1975), p.227.

2. State of New Jersey, County and Municipal Government Study Commission, Hous

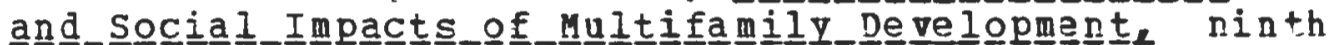
repoIt, p.78, in Michael N. Danielson, The_politicics off.Exc드노으으 (New York: Columbia University Press, 1976), p. 52 .

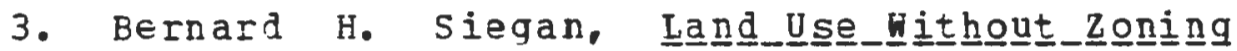
(Lexington, Mass.: Lexington Books, 1972).

4. R. Robert Linowes and Don T. Allensworth, The

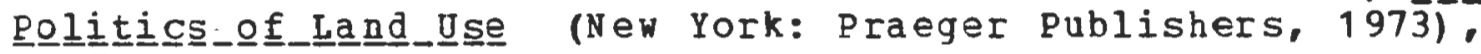
p. 74 .

5. National Commission on Jrban Problems, Buiiㅍigㅁ

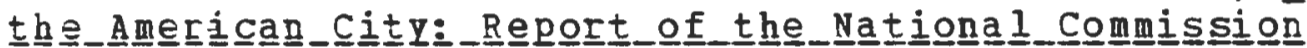

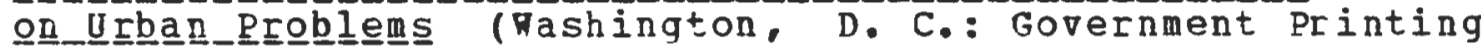
office, 1968), p.219.

6. Daniel Mandelker, exerpts from, "The Role of Zoning in Housing and Metropolitan Development", in David

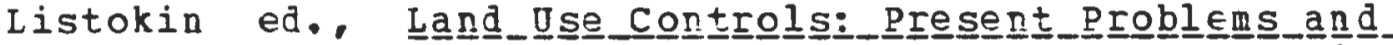

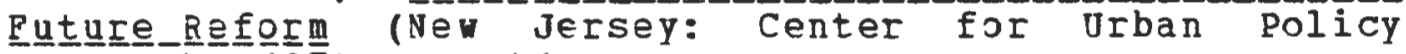
Research, 1974), p. 41.

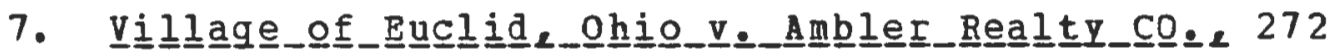
U. S. 365,47 S. Ct. 114, 71 L. Ed. 303 (Supreme Court of the United States, 1926).

8. National Commission on Urban Problems, Buui르믐 thhe American_City (Nashington, D. C.: Government Printing office, 1968), p. 215 .

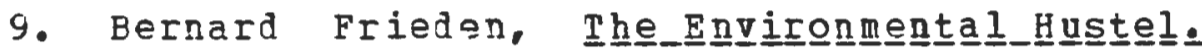
(Cambridge, Mass.: MIT Press, 1979).

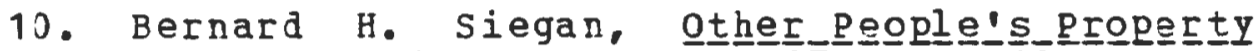
(Lexington, Mass.: Lexington Books, 1976), p. $3 \overline{8}$. 


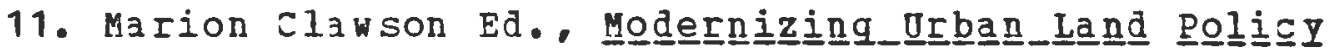
(Baltimore, Maryland: Johns Hopkins Oniversity press, 1973), pp. 237-8.

12. Lynne B. Sagalyn and George Sternliob,

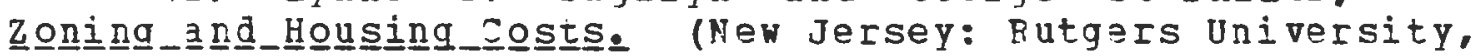
1972). Ihis study used the range of 15,000 to $20,000 \mathrm{sq}$. ft. as the basis for a large-lot requirement.

13. Ib $\underline{\text { id }}$. This stady also identified $1,000 \mathrm{sq}$. Et. as a cut off point for large home size requirements. 
III. LEGAL CHALLENGES TO EXCLUSIONARY ZONING 
Ihis section is concerned with the legal questions raised by exclusionary zoning practices. some of the key cases decided by both the federal and state court systems will be reviewed. The cases covered will not exhaust the subject matter, but will highlight the decisions concerning exclusionary zoning.

Within this selective review, an identification of the current positions taken by the courts will be formulated.

All qovernment $\in$ fforts to manage growth must conform to established constitutional limitations on governmental IEqulations of private action. These constitutional provisions established the framework within which development timing strategies could be designed. The courts can declare any progran which goes beyond these limitations unconstitutional, and therefore invalid. If, for example, in an effort to control the timing of development, the community imposes a regulation which restricts the rights of landowners to develop their land and does not compensate them for this 1oss, or potential finarcial 1osses, the court can determine that the land has been constructively taken for public use and that the requlation is therefore invalid. Thus, any development timing technigue must fall within this and other constitutional limitations on qovernmental action. 
An urderstanding of the constitutional constraints on growth management is a vital prerequisite to the formulation of any system of development timing.

The basic source of these constraints is the Inited States constitution, particularly the Fifth and Fourteenth Amendments. These provisions, as they have been interpreted by the courts, prohibit any unit of government, federal, state, or local, from taking any action which appropriates private land fcr public use without the payment of compensation, or which unfairly discriminates between similarly situated persons. Furthermore, the courts have also found that necessarily implied in the Constitution is the right to move about freely and settle in any place, even though no such "right to travel" is

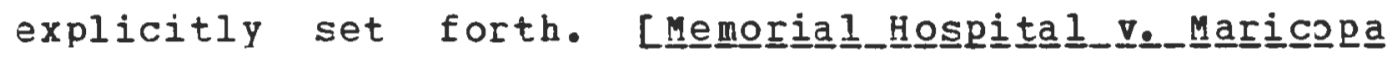

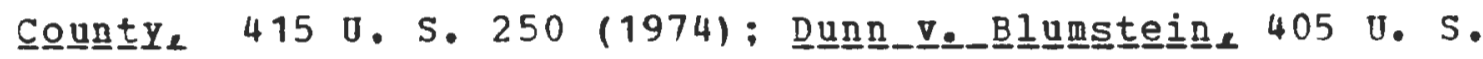
$330(1972) \cdot]^{1}$

Although the law is changing and definitive statements about the constitutionality of recently developed growth control techniques are not possible, previous court pronouncement: provide three general guidelines. First, policies which have the effect of continuing racial discrimination will be declared unconstitutional. Second, states and localities are prohibited from zhoosing means that unnecessarily burden or restrict a constitutionally protected activity. Therefore, the courts are more likely to invalidate an ordinance if 
there are less restrictive growth management tools available to achieve comparable governmental ends. 2 Finally, although the judicial imperative that land-use and community development plans meet the demands of equal protection appear too stringent and too uncertain to allow free use of planning techniques, in actuality, the requirements of equal protection support rather than undermine rational planning efforts.

If the technique being challenged is related to a sensible and comprehensive plan, the test of rationality can often be met. If the plan is developed on the basis of a reasonable geographic area in which the rights of individuals and the needs of all groups are considered, protection of basiz riqhts and avoidance of discrimination will be part of its natural evolution.

The "taking issue," in and of itself, is no real obstacle to managed growth. Courts have upheld a wide range of regulations, some of which reached beyond the normal limits of control. What is crucial to a municipality's successful defense of its proposed requlation is an accumulation of evidence to support the need for the control. The most convincing kinds of evidence, in terms of judicial acceptance, are legislative reports, planning reports, and scientific evidence of ecological and other environmental (both physical and social) factors. Without these kinds of support, a gov arnmental defendant has cnly the uncertain hope that the 
courts will liberally apply the precedents on the taking issue. A community is on firmer ground if it shows evidence that the purpose of the restriction falls within the definition of a valid police power action. Usually, courts presented with material of this kind will uphold stringent regulations.

Two cases seem to give some insight into the position of the courts on the issue of growth control techniques in general, and large-lot zoning in particular. The court in

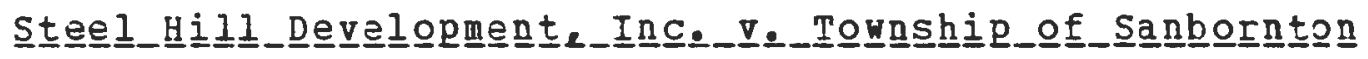
upheld an ordinance which required three-acre and six-acre minimum lots in certain zones. 3 This case dealt with the desire of a developer to construct vacation homes, but this fact should not have entered into the decision. The court noted that such an ordinance must be within the purview of established police power purposes-- health, safety. welfare, and morals-- despite the fact that the court was "disturoed by the admission here that there was never any professional or scientific study made as to why six, rather than four or eight acres was reasonable to protect values cherished." While the outcome of this case was farorable to the community, it is obvious that planners could have maje a valuable contribution towards strengthening it.

In fact, it may be crucial for planners to be utilized more frequently when ordinances concerning land-use are being prepared. other courts may not as easily overlook the lack of scientific surveys underlying 


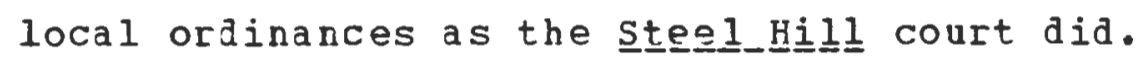

The other case, which held a zoning ordinance with four-acre minimum lots invalid based on a lack of technical support, offers further insights into this problem. The

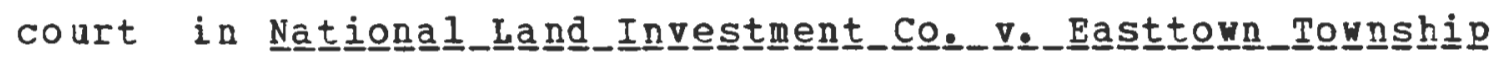

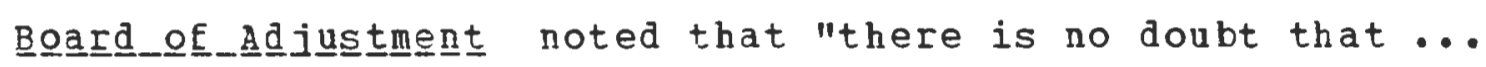
zoning for density is a legitimate exercise of the police power ... Therefore, it is impossible for us to say that any minimum acreage refuirement is unconstitutional per $s \in .114$

The court found for the landowners on the basis of the commity's failure to show the public purpose behind the minimum acreage requirements. It appears that courts will be willing to uphold certain minimum lot size requirements provided that local governments provide ample proof that the restrictions are required for environmentally sound development.

PEIhaps the most insidious aspect of zoning is that it can be perverted to accomplish questionable ends. Initiated as a land-use tool much needed to accelerate orderly growth and development of urban and urbanizing areas, zoning can, and frequently does, achieve unstated and undemocratic objectives.

currently, new approaches for economic and ethnic exclusion are emerging. Wrapping themselves in the popular 
cause of concern for the ecology, opponents of multi-family and lower-income housing speak of the problems of water and sewers, waste disposal, and high densities, others, still, raise the issues of overcrowing in schools and traffic congestion.

Several ways of dealinq with exclusionary techniques come to mind. The first is to abolish zoning, which Bernard Siegan has so explicitly stated.5 That approach, like most simplistic ones, leaves much to be desired. Zoning offers many positive benefits, and its destruction would be a step backward in the process of orderly land-use and development.

Litigation is the most likely method for challenging this type of restrictive zoning, but it has three princioal limitations: it can be time-consuming, expensive, and it usually is applicable only to the most obvious and extreme abuses. Favorable decisions, at best, ban certain actions; they do not establish affirmative programs that can offset or compersate for the rational economic, and the popular ecological opposition to lower-income residents in the suburbs.

It is extremely difficult to differentiate between class and color aspects of suburban exclusiveness, but this much is clear, there is opposition to low- and moderate-income families of all ethnic backgrounds in the suburbs, and this becomes accentuated when the element of color is introduced. 
Four groups have been particularly active in contesting exclusionary zoning; land owners and developers, citizens or residents, special interest groups or the surrounding communities, and other open-housing advocates. Also, three distinct shifts in the primary participants have been noted; from the 1900 s to 1928, when the power was generally in the hands of the landowners, to the mid 1960s, when the emphasis was primarily on the commuities, and to the present, where the tendency is to focus on regional problems.

Judicial reviews have tended to seek guidance in past legal authorities and precedents in resolving zoning ordinance conflicts rather than basing their judgments on the non-legally binding comprehensive plan. As a result, long term emphasis on planning could be eroded by the legal system. However, recent trends suggest that "legal advocacy" could become a force, itself, in determining future shifts in zoning attitudes.

A major component to the legal challenge approach to exclusionary zoning is the choice of forum the litigaton is presented in. The choice of forum, either federal or state, makes a significant difference to the desired outcome. It is this aspect of the legal challenge to restrictive practices that I will now address.

First, as a general rule, federal judges tend to be more liberal than the judges in the state courts. Thus, one would expect that federal courts would tend to be more 
receptive to the contention that exclusionary zoning violates constitutional rights.

second, fejeral courts operate under the restraint of limited jurisdictions. Because of this fact, it is usually easier to obtain jurisdiction in the state courts rather than in the federal courts. 6

Third, once the federal court accepts jurisdiction, there is a greater likelihood that any relief granted will be of a broad nature.?

Fourth, state courts have had more experience in reviewing zoning cases. ${ }^{8}$ It is the state courts, for the most part, which have failed to treat the issues of exclusion in an enlightened manner.9

Fifth, if the case involves racial discrimination, it will be received easier in the federal courts than in the state courts. If the case involves economic discrimination, however, state courts may be more likely to react favorably to the case than the federal courts.

Sixth, if the case can be viewed as a violation of a right granted by a federal statute, then it should be filed in federal court.

The choice between a federal and state forum must be, therefore, based upon a comparison of jurisdictional requirements, substative law and the anticipated receptivity of indiridual judges in addition to the points just raised. 10

Tppically, in an exclusionary zoning lawsuit, the 
site in question is zoned in such a way that the project which the developer is proposing may not be built unjer its Existing zoning classification. The developer could then appeal to the governing body of the muricipality to change the zoning of the site. In most states, this reguest is regarded as a legislative exercise. In other states, the decision to change the zoning classification of a particular parcel is regarded as a qusi-judicial function. The difference between these two points of view determines the prozedure followed and the level of judical review. In the states where the decision whether or not a particular parcel should be rezoned is regarded as a legislative decision, it is very difficult to convince a court to reverse the decision of the governing body of the municipality.

Also, there are non-constitutional issues which the developer may raise. He may contend, for example, that his site is illegally zoned because of "spot zoning."11 While the issue of spot zoning may be raisea as to any size parcel, it is usually related to rather small parcels.

on his own behalf, the developer could argue that the effect of the zoning ordinance is to deny him any reasonable use of the land.

other grounds have also been cited in an individuals challenqe of restrictive zoning practices. The argument as to due process as it concerns the future resident has been developed almost entirely within the state courts. When 
invalidating exclusionary zoning ordinances, the federal courts have relied most heavily upon the equal protection clause and the civil rights acts. There have been no federal invalidations of exclusionary zoning on substantive grounds in suits brought by future residents in which the basis for invalidation was the due process clause.

Communities cannot formulate their zoning regulations based upon their understanding of the best interests of their present residents only. The concept of "general welfare" must be considered from the point of view of all the inhabitants of the state and must not be limited to those individuals who are fortunate enough to presently reside in that community. This reasoning was first expressed in Justice Hall's famous dissenting opinion in

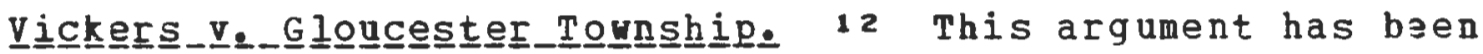
developed most impressively by the state courts in Pennsylvania and New Jersey.

As stated earlier, virtually all zoning litigation has been brought to test in the state courts. These courts tested local actions against the requirements of state law that any exercise of the police power must promote the public health, safety, and general welfare.

Regardless of what happens in the federal courts, the state courts will undoubtedly continue to exercise their power to determine the wisdom of local zoning decisions according to their own view of the general welfare. Norman williams has expressed distress that "the prevailing 
intelleatual equipment ... is merely vague, and ... practically leaves it up to a judge's preferences to choose his presumptions and decide on the validity of public regulations."13

The United states supreme court first invalidated a zoning ordinance specifically prohibiting occupation of housing by minorities in 1917.14 It based its decision on "the fundamental law enacted in the Fourteenth Amendment of the constitution preventing state interference with property rights except by due process of law."

In subsequent years, the court has changed its focus on racial discrimination from property rights of the landowner to the civil rights of the excluded party. Since 1917 the supreme court has not ruled on a zonirg case based on racial motivations. The federal circuit courts have invalidated such decisions, however, in two important cases: the tenth circuit court ordered the city of Lawton, oklahoma to rezone propety for a low- and moderate-income housing project when it found the refusal to rezone was motivated by "a desire to maintain racial segregation;" 15 the second circuit court has overturned the refusal of the City of Lackawanna, New York to permit the construction of a low- and moderate-income housing project where the refusal was clearly attributable to the fear that the project would allow Blacks to live in an all- rhite neighborhood.16

Because of the difficulty in proving racial 
discrimination, civil rights groups have sought to establish the principle that any local regulations which precluãe the construction of low- and moderate-income housing are invalid because they discriminate against the poor.

The arqument that discrimination against poor persons creates a violation of the equal protection clause is of recent origin. The use of the equal protection clause to attack economic discrimiration added a major new weapon to the civil rights lawyer's arsenal.

The second circuit court of appeals relied in part on the right of the poor to equal protection when it enjoined the City of Norwalk, Connecticut from conducting its urban renewal program in a manner that had the effect of forcing poor people to leave the city.17

No one can even predict the ultimate outcome of the current debates about the constitutionality of local land-use practices. Even if the onited states supreme court will accept a case that outright raises the issue, and even condemns exclusionary zoning, the issue will not be settled. Only one case involring one community and one site will have been settled.

The most important role of the courts, however, is to zct as a predicate of legislative reform. The courts can dramatize the absurdities and inequalities of a divided 
system of governmental regulations designed for a simpler time, and create real pressure for change.

To place this all in perspective, this study will examine what the federal judiciary has declined to do. First, there has been a reluctance, indeed a refusal, to equate exclusion on economic grounds with exclusion on the basis of color. The various low-income zoning referendum cases all point to this fact. In James_r. V. Valltiengra. the United states supreme court upheld the validity of a state constitutional provision wich required approval by a majority of the electorate in a community as a condition to locating a low rent project within the municipality.18

Several prior courts of appeals cases had reached the

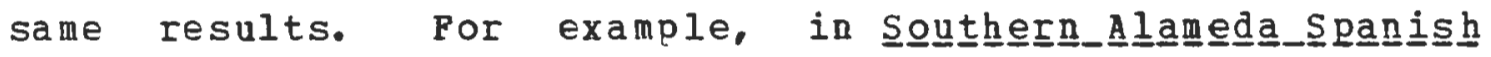

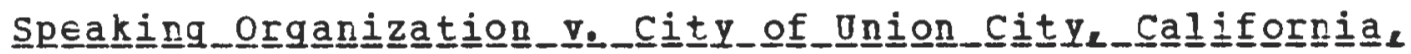
the court refused to inquire into the motives of the voters in rejecting low-income housing.19 In this case, the assocition of low-income persons with Blacks was clearly evident.

secondly, a troublesome issue exists in zoning cases in that the federal judicial remedy offered by the courts often is of little consequence to the plaintiff. The typical approach has been to declare the ordinance invalid and let it go at that! To aroid this result, a few jurisdictions have followed a practice of not declaring the ordinance invalid as a whole, but granting relief to the particular claimants. 
These weaknesses in the legal forum of dealing with exclusionary zoning have been recognized for many years. Just going to court does not insure suzcess for any group. Traditionally, legal action has been used as a last resort in zoning and housing disputes. Por groups interested in building housing in the suburbs, litigation also offers a means of bringina pressure to bear on local governments. Developers and landowners have long used the threat of court action to bolster their positions in negotiations.

The final risk in relying on the courts to open the suburbs is the likelihood that most victories in zoning cases will have limited impact on housing opportanities across the nation. By its nature, suburban zoning does not $l \in$ nd $i$ tself to the kind of sweeping judicial pronouncements which began the desegregation of our schools.

Awareness of these limitations, however, has not lessen $d$ the heavy dependence of the open-housing movement on legal action. Nor, apparently, have the numerous delays and setbacks suffered in the courts by the foes of suburban exclusion. Despite its limitations, litigation remains fairly well suited to the talents and resources present among the organizations seeking to open the suburbs. Judicial holdings can initiate action that open-housing interests could never accomplish on their own.

since 1968, federal housing subsidy programs have 
provided mechanisms for developing increased numbers of privately sponsored housing units for lower-income households in suburban areas. These programs faced barriers in some suburban communities such as requirements of large lots or prohibition of multi-family housing. As a result, courts in Pennsylvannia, New Jersey, and New York were faced with challenges to overly restrictive zoning regulations. One of the landmark decisions wherein municipal land-use regulations were challenged is

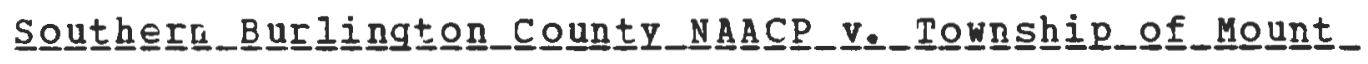
Laㅡ므들. In 1975, the New Jersey high court held that municipal land-use regulations must serve both the reeds of the residents of Mount Laurel and the general welfare of the population within the metropolitan area. The court held that:

\footnotetext{
We corclude that every such municipality must, by its land use regulations, presumptively make realistically possible an appropriate variety and choice of housing. More specifically. presumptively it cannot foreclose the opportunity of classes of people mentioned for low and moderate income housing and in its regulations must affirmatively afford that opportunity, at fair share of the present and prospective regional need therefore. 20
}

In New York State, the New York Court of Appeals decided another important case against the misuse of local

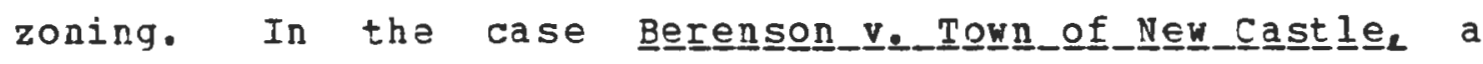


landown $=r$ attempted to develop multi-family housing which was prohibited by local zoning regulations. The court, in ruling in favor of the landowner, set forth a goal for municipal land-use ordinances. It said:

The primary goal of a zoning ordinance must be to provide for the development of a balanced, cohesive community which will make effecient use of the town's available land. 21

The court provided a two-part test for determining the validity of a local land-use ordinance: (1) the extent to which the zoning ordinance provides an acceptable level of housina opportunities is dependent upon whether the existing housing stock in the municipality meets the community's current housing needs and what additional housing might be reguired for its future needs; and (2) the extent to which the zoning ordinance reflects a consideration of regional needs and requirements is dependent upon a balancing of the local desire to maintain the status quo within the commity and the greater public interest that regional needs be met. 22

Once again it is the progressive state court systems which have provided us with these enlightened holdings. Ultimately, it is the state court system which must crack down on $E x c l$ usionary zoning practices. Nith the failure of 
the federal courts to adequately immerse themselves in most land-use concerns, open-housing advocates, conscientious planners, and informed citizens must increasingly rely upon state judges to effect any policy changes.

An active judicial role, moreover, invites an appropriate political response, namely, that the local legislature is initially better suited than a court for preparing new zoning provisions and policies.

A report of the American Bar Association Advisory Comission on Housing and Urban Growth concluded that courts zan fashion effective remedies and thus holp to bring about fundamental changes in metropolitan housing patterns. 23 In adition, the Advisory Comission notes. with approval, a growing trend of the courts to evaluate growth management techniques in light of their impact on lower-income housing.

It can be safely asserted, however, that a siqnifizant trend is emerging, and we have not seen the last of litigation involving the validity of exclusive zonirg ordinances and practices. Hopefully, the federal court system will become involved and provide decisions more far-Ieaching than the ad hoc state court approach. 


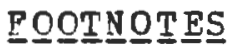

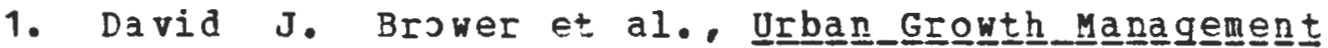

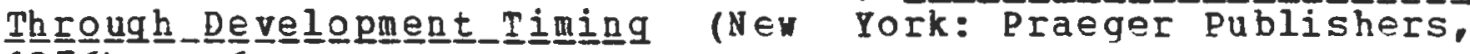
$1976), p .6$.

2. I믈. , p.23.

3. 469 F.2d 956 (1st. Cir., 1972).

4. 419 Pa. 504, 215 A. 2d 597 (1965).

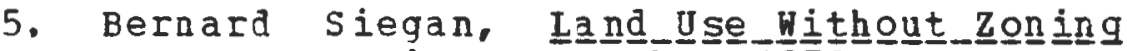

(Lexington, Mass.: Lexington Books, 1972).

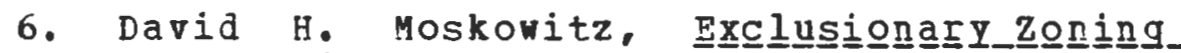

Litigation (Cambridge, Mass.: Baliinger Publishing, 1977). p. 66 .

7. I믈.

8. Richard Babcock, "On the Choice of Forum," (27 Land Usミ Law and Zoning Digest, 7, 1975), pp.7-8.

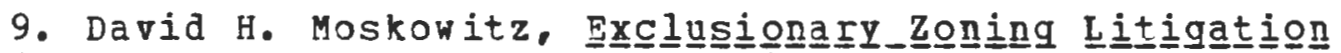
(Cambriage, Mass.: Ballinger Pubishing, 1977).

10. James C. Quinn, "Challenging Exclusionary Zoning: Contrasting Recent Pederal and State Court Approaches," (4 Fordham Urban Law Journal, 1975), p.147.

11. The term spot zoning means the improper permission to use an "island" of land for a more intensive use than permitted on adjacent properties.

12. 37 N. J. 232, 252, 181 A. 2d 129, 140 (1962). appeal dismissed, 371 0. S. 233,83 S. Ct. 326,9 I. $\in d .2 d$ $495(1963)$.

13. Norman Williams, "Planning Law and the supreme Court," Zonningq_ㅁigesst 13 (1961): 57 , p.64. 


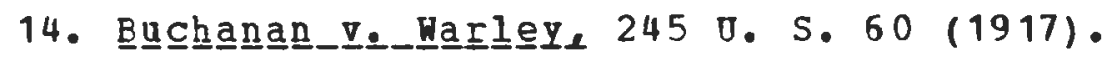

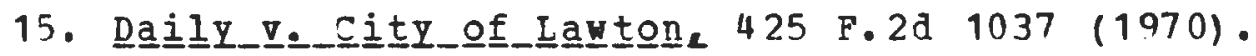

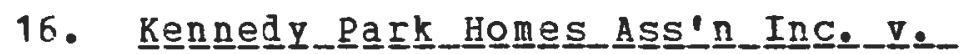

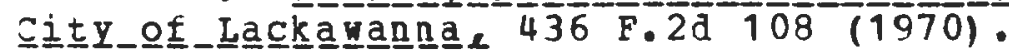

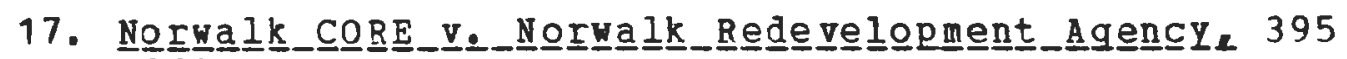
F. 2 d $920(1968)$.

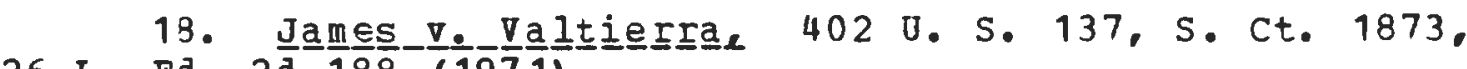
26 I. Ed. 2 d $188(1971)$.

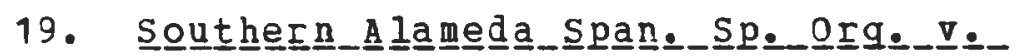

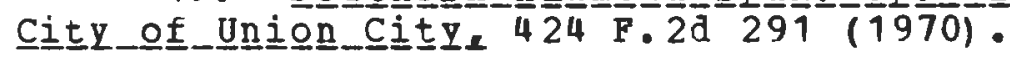

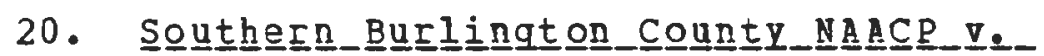

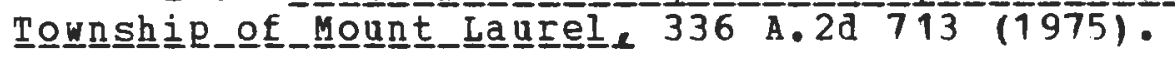
(1975).

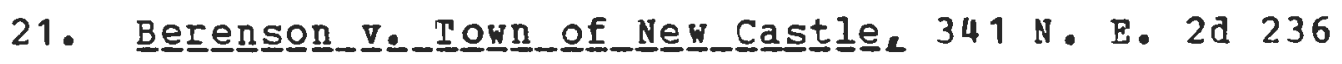
22. I I $\underline{\text { bi }} \underline{\underline{d}}$.

23. American Bar Association, "Housing for All Under Publishing, 1977), p. 15 . 
IV. WASHINGTON COUNTY SELECTED SOCIAL CHARACTERISTICS 
The analysis of a municipality's zoning practices can not be viewed from an isolated perspective. Important social corditions within each community must be addressed to provide us with an appropriate base to work from. Fach community practices its zoning with the knowledge of its own particular characteristics. Each community under review is itself a part of a larger region, as well as being a part of the state. Therefore, characteristics of the communities, the county in which they are located, and the state were studied for the purpose of establishing a framework for the zoning ordinance analysis. The purpose of this section is to identify and analyze these characteristics.

The characteristics identified for review were selected to assist in making a determination as to whether classes of people are discriminated against in their choice of obtaining housing.

The data compiled for each community, the county, and the state provides a base for appraising whetber or not a particular town has "grown" and whether or not it has a wide range of participation from the total available populatior.

This section correlates data that reflects two social objectives affecting individuals who are currently seeking. or who may soon be seeking, housing. These objectives are growth and balance.

population, income and employment growth have been 
the traditional concepts of such analysis. One set of information examined in this section looks at whether there has been quantitative changes in the population, income. employment, and housing units in washington county.

The second concern is that of balance. The term is used here to reflect the mix of residents that demonstrates fair representation of different groups. A com munty is designated as balanced or imbalanced in terms of the proportion of different population and income groups contained within it. In these terms, commuity growth can also be seen as being either balanced or not.

The information obtained in this section should yield strong evidence to assist in evaluating zoning performance. While explicit cause and effect relationships will not be obtained, valuable insights into the possible negative effects of zoning on a community's profile will be available.

First, the information selected for review in this section will be presented. From this base, an analysis of the data in relation to concerns of growth and balance will be conducted. This analysis will be followed by conclusions pertinent to this investigation.

The basic information collected for this study dealt with Washington Count's population and its changes. special attention was given to the participation of 
minorities and female heads of households.

The second set of data analyzed concerns new employment opportunities in Washington county and the state. The intent here was to discover if those jurisdictions where employment was expanding vere receptive to new population as well as additional employment. Further, there was a concern that while population and job growth might be equal, growth would not be balanced. In other words, communties benefitting from the tax and work advantages of new commercial or industrial activity, may tend to include or exclude minority populations from sharing in those benefits.

Another major area of concern is that of shifting patterns of income in a community. While zoning is often challenged for its discriminatory effect on racial minorities, zoning restrictions do not establish bars to Blacks and other minority groups. If zoning does have a negative racial or ethnic impact, it is generally because the controls employed exclude persons of lower income. Because Blacks and other minority groups, along with female heads of households, tend to be poorer than the white male population, such zoning tends to disproportionately restrict their opportunities. It is, therefore, most important to observe hat income groups have access to a community over time.

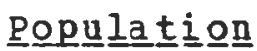

The population of Rhode Island has been increasing 
steadily since 1900, though growth appears to have been Ieverse $\mathfrak{Z}$ between 1970 and 1975.1

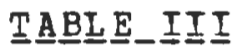

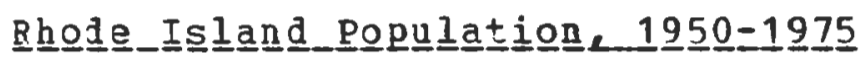

Total Population $\quad 79 \frac{19}{1}, \frac{5}{8} \frac{0}{96} \quad 85 \frac{1}{9}, \frac{6}{4} \frac{0}{8} 8 \quad 94 \frac{1}{9} \frac{9}{7} \frac{0}{00} \quad \frac{1}{9} \frac{9}{31} \frac{5}{0}, 000$

Source: U. S. Bureau of the census

* Estimated

The major cities in Rhode Island, once dominant in population, are now declining in comparison to the suburbs. In 1960, the eight major cities of the state (harwick, Newport, Central Falls, Cranston, East Providence, Pawtucket, Providence, and woonsocket) had 67.4 perzent of the State's population.2 By 1970 they had only 59.2 percent of the state's population and by 1975, it is estimated to be only 59 percent. 3

Between 1950 and 1970 the population of these eight cities decreased from 575,394 to 562,386 , while the population of the state as a whole increased from 791,896 to $949,723.4$ This shows that almost all of the increase in the State's population between 1950 and 1970 took place outside the central cities of these eight areas. This growth occurred in the suburban and rural areas of the 
state.

\section{T스므트프}

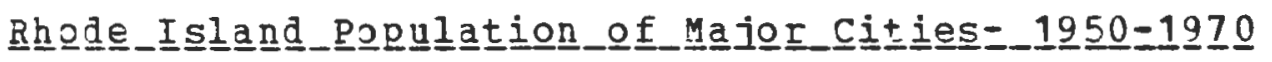

\begin{tabular}{|c|c|c|c|}
\hline 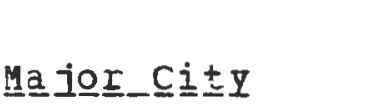 & $19 \underline{5} \underline{0}$ & $19 \underline{90}$ & $\begin{array}{l}\text { change } \\
19 \underline{5} \underline{0}=19 \underline{7} 0\end{array}$ \\
\hline $\begin{array}{l}\text { Warwick } \\
\text { Newport } \\
\text { Central Falls } \\
\text { Cranston } \\
\text { East Providence } \\
\text { Pawtucket } \\
\text { Providence } \\
\text { Woonsocket }\end{array}$ & $\begin{array}{r}43,028 \\
37,564 \\
23,550 \\
55,060 \\
35,871 \\
81.436 \\
248.674 \\
50.211\end{array}$ & $\begin{array}{r}83,694 \\
34,562 \\
18,716 \\
74,287 \\
48,207 \\
76,984 \\
176,116 \\
46,820\end{array}$ & $\begin{array}{r}94.5 \\
-7.9 \\
-20.5 \\
34.9 \\
34.3 \\
-5.4 \\
-27.4 \\
-6.7\end{array}$ \\
\hline $\begin{array}{l}\text { Total } \\
\text { State }\end{array}$ & $\begin{array}{l}575,394 \\
791,896\end{array}$ & $\begin{array}{l}562,386 \\
949,700\end{array}$ & $\begin{array}{l}-2.2 \\
19.9\end{array}$ \\
\hline
\end{tabular}

Source: U. S. Bureau of Census

Khode Island towns experiencing the greatest increases appear to fall into two categories: (1) Suburban communities surrounding the major urban centers, and (2) Suburban "centers" such as Narragansett, North Kinqstown, Middletown, Rest Greenwich, and East Greenwich.

With the decline in growth of the major urban centers, many suburban and rural areas have nearly "exploded" due to the growth. This shift in population, from the cities to the suburbs, resulted in severe 
developnent pressures within the latters boundaries.

This is the situation faced by most of the

commities in Washington County. Between 1950 and 1970 the population has increased from 48,542 to 85,706, a 76 percent increase.5 Between 1960 and 1970 alone, Washington County led the State in growth with a 43.9 percent increase in its population.6 It was based on these increases, along with the continued projected growth, that many washington County community's adopted their present zoning regulations to help deal with the surge in population.

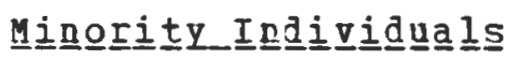

The space dividing rich and poor, Black and Thite, and female headed households from male headed households grows increasingly wider in Rhode Island every year. The cities grow poorer and absorb more of the minority groups of the state. On the other hand, the suburbs increase their relative affluence. This process of separation of classes of population mirrors a process occurring in most older urbanized regions in the nation.

of the State's 1970 population of 949,700 , only 31,968 or 3.3 percent vere of a minority background. 7 The same census data identifies only 1,612 minority individuals in Washington County. This figure represents 1.8 percent of the county's population at the time of the census. Ihis low number of minority individuals in washington county indicates an uneven mix of minority residents in the state. While Washington county contained nearly 10 percent of the 
State's population in 1970, it afforded residence to only 5 percent of the State's minority population.

For Washington county to house its "regional fair share" of the state's minority individuals, it would have to double its prəsent minority population, a feat which appears difficult to achieve at the present time.

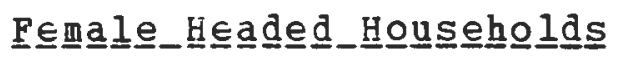

Data exists on the number of female heads of households in 1970 only for communities with populations above 10,000. Female heads of households are defined as households in which there is no husband present. On a relative basis, ashington county compares quite favorably with the remainder of the state in the number of female headed households. Of a total of 235,183 households in Rhode Island as counted by the Census, 28,439 , or 12 percent. were headed by females. The number of female headed householis in Washington County was 2,015, or 11 percent out of a total of 16,305 households in 1970.8

This information appears to indicate that householis headed by females were generally not excluded from Washington County as of 1970.

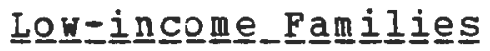

The 1970 zensus provides data on the percentage of population earning incomes below the poverty level, with a poverty formula adjusted for family size, cost of living, as well as other factors. This information is available for all commuties over 2,500 in population. For the 
purposes of this study, the Census data was supplemented by income distribution data from the Fourth count of the Census for the communities with populations under 2,500 . In these communities, the poverty population consists of all families with an annual income under $\$ 4,000$. Table $V$ identifies the proportion of families with annual incomes below the porerty level in 1970 in each of the communties of Hashington county.

\section{I}

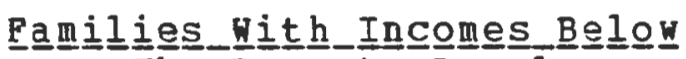

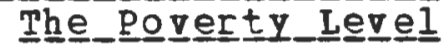

\begin{tabular}{|c|c|c|}
\hline & $\begin{array}{l}\text { Total } \\
\text { Number of } \\
\text { Pamilies }\end{array}$ & $\begin{array}{l}\text { Percent of } \\
\text { Potal Below } \\
\text { Poverty Level }\end{array}$ \\
\hline $\begin{array}{l}\text { Town } \\
\text { Charlest own }\end{array}$ & 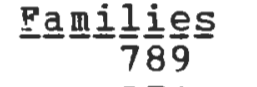 & 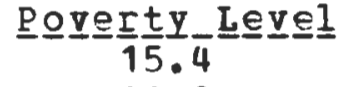 \\
\hline Exeter & 579 & 11.0 \\
\hline Hopkintor & 1,364 & 11.1 \\
\hline Narragansett & 1.804 & 11.1 \\
\hline New Shoreham & 117 & 11.1 \\
\hline North Kingstown & 5,932 & 17.7 \\
\hline Richmond & 629 & 8.5 \\
\hline South Kingstown & 3,176 & 9.1 \\
\hline Westerly & 4,462 & 9.1 \\
\hline $\begin{array}{l}\text { County rotal } \\
\text { State Total }\end{array}$ & $\begin{array}{r}18,852 \\
236,667\end{array}$ & $\begin{array}{l}12.5 \\
12.5\end{array}$ \\
\hline
\end{tabular}

Source: Gereral Social and Economic Characteristics 1970 Census of population.

The proportion of low-income residents living in Washington county corresponds exactly to the proportion residing in Bhode Island, each contain 12.5 percent. Looking at the median family income for washington 
County, the state, and the individual communities involved in this investigation shows a slightly different relationship. For this element, the state in 1970 had a median family income of $\$ 9.736$, while Nashington County maintained a level of $\$ 9,607$. 9 Figures for the individual communities in washington county are contained in Table VI.

\section{$\underline{\underline{T}} \underline{\underline{B}} \underline{\mathrm{B}} \underline{\mathrm{E}}-\underline{\mathrm{V}} \underline{\underline{I}}$}

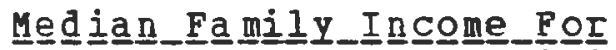

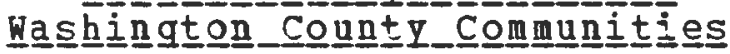

\begin{tabular}{|c|c|c|c|}
\hline $\begin{array}{l}\text { Toun } \\
\text { Charlestown } \\
\text { Exeter } \\
\text { Hopkinton } \\
\text { Narragansett } \\
\text { New Shoreham } \\
\text { North Kingstown } \\
\text { Richmond } \\
\text { South Kingstown } \\
\text { Westerly }\end{array}$ & $\begin{array}{r}19 \frac{6}{9} \frac{9}{2} \\
9.802 \\
9.327 \\
9.438 \\
9.919 \\
8.289 \\
9.002 \\
9.461 \\
10.052 \\
10.074\end{array}$ & $\begin{array}{l}1 \frac{19}{9} \frac{9}{2} \\
5.932 \\
5.412 \\
5.862 \\
5.442 \\
3,935 \\
5,031 \\
5.745 \\
5.440 \\
6,349\end{array}$ & $\begin{array}{l}19 \text { Increase } \\
19 \frac{59}{65}=\frac{19}{2} 69 \\
72.3 \\
61.0 \\
82.3 \\
110.6 \\
78.9 \\
64.7 \\
84.8 \\
58.7\end{array}$ \\
\hline $\begin{array}{l}\text { County Total } \\
\text { State Total }\end{array}$ & $\begin{array}{l}9,607 \\
9,736\end{array}$ & $\begin{array}{l}5,635 \\
5,563\end{array}$ & $\begin{array}{l}70.5 \\
74.2\end{array}$ \\
\hline
\end{tabular}

Source: Department of Economic Development Basic Economic Statistics

For the period 1959 through 1969, Washington County's median income grew at a slower rate than the state. From a 1959 position favorable to that of the state, (actually above the state levell, Washington county had fallen below 
the State level by 1969. During this period, Washington county rated last as compared to the remainder of the State's counties in absolute growth of median family incomes.

Four of the rine communities, Charlestorn, Hopkinton, Richmond, and Westerly grew at a rate less than both the county and the state's. This information is valuable in determining the buying power of families which are looking for housing in Washington County.

The number of families which fall within designated income groups can help to clarify this situation. The following tables show the percent of families per incone group for each of the communties within washington county: 


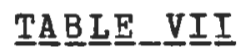

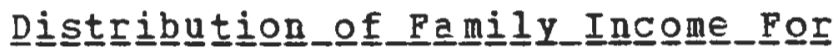

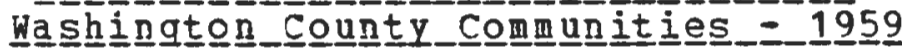

T으브므

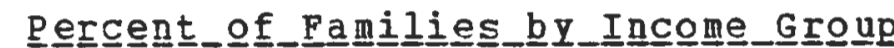
under $\$ 2000 \quad \$ 4000 \quad \$ 6000 \quad \$ 8000-\$ 10000$

$\varepsilon$ to to to to to

$\$ 2000 \quad \$ 3999 \quad \$ 5999 \$ 7999 \quad \$ 9999 \quad$ E over

$\begin{array}{lrrrrrr}\text { Charlestown } & 6.8 & 20.4 & 23.5 & 27.4 & 17.1 & 4.8 \\ \text { Exeter } & 7.7 & 19.8 & 32.0 & 23.2 & 8.8 & 8.5 \\ \text { Hopkinton } & 9.4 & 14.3 & 28.7 & 28.5 & 12.4 & 6.6 \\ \text { Narragansett } & 6.7 & 19.3 & 29.0 & 21.8 & 10.3 & 12.9 \\ \text { New Shorenam } & 25.0 & 26.1 & 23.2 & 13.1 & 6.3 & 6.3 \\ \text { N. Kingstown } & 11.4 & 22.8 & 30.1 & 17.7 & 8.0 & 10.0 \\ \text { Richmond } & 9.3 & 14.4 & 31.3 & 25.4 & 8.9 & 10.7 \\ \text { S. Kingstown } & 7.9 & 22.5 & 27.5 & 16.8 & 10.7 & 14.6 \\ \text { Mesterly } & 5.3 & 13.6 & 26.4 & 24.1 & 14.3 & 16.3 \\ \text { County Total } & 9.9 & 19.2 & 27.9 & 22.0 & 10.7 & 10.0 \\ \text { State Total } & 9.5 & 18.3 & 28.4 & 21.2 & 10.9 & 11.7\end{array}$

Source: Rhode Island Department of Economic Development Basic Economic Statistics - 1968 


\section{$\underline{T}$ A $\underline{B} \underline{\underline{E}} \underline{\mathrm{E}} \mathrm{V} \underline{\mathrm{I}} \underline{\underline{I}} \underline{\underline{I}}$}

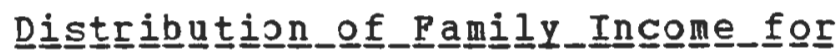

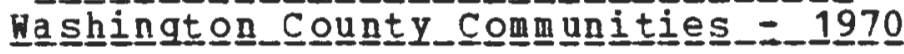

뜨으므

\begin{tabular}{|c|c|c|c|c|c|}
\hline & 14 & 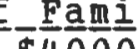 & $=\frac{D}{2} Y$ & 든 쓰은 & 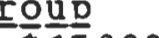 \\
\hline $\begin{array}{c}\varepsilon \\
\$ 2000\end{array}$ & $\begin{array}{r}\text { to } \\
\$ 3999\end{array}$ & $\begin{array}{r}\text { to } \\
\$ 6999\end{array}$ & $\begin{array}{r}\text { to } \\
\$ 9999\end{array}$ & $\begin{array}{c}\text { to } \\
\$ 14999\end{array}$ & over \\
\hline
\end{tabular}

Charlestown

Exeter

Hopkinton

Narragansett

New Shoreham

N. Kingstown

Richmond

$\$ 2000$

$\$ 3999$

$\$ 6999$

$\begin{array}{rrrrrr}4.9 & 11.7 & 19.0 & 16.7 & 33.7 & 15.0 \\ 3.2 & 7.8 & 18.9 & 28.9 & 29.3 & 12.1 \\ 4.6 & 6.4 & 15.6 & 30.2 & 27.7 & 15.3 \\ 3.9 & 8.0 & 16.7 & 22.0 & 27.6 & 21.5 \\ 0.0 & 11.1 & 29.0 & 27.3 & 27.3 & 5.1 \\ 10.9 & 6.7 & 19.2 & 20.6 & 23.5 & 18.8 \\ 2.0 & 6.5 & 24.0 & 22.8 & 32.9 & 11.6 \\ 2.2 & 6.9 & 18.3 & 22.1 & 25.9 & 24.3 \\ 3.5 & 5.5 & 17.0 & 23.3 & 31.4 & 19.1\end{array}$

County Total

5.7

6.8

18. 2

22.5

27.4

19.1

State Total

4.

7.6

16.4

23.129 .0

18.8

Source: Rhode Island Department of Economic Development Basic Economic Statistics - 1970

To compare the 1970 figures to the 1959 figures for the purpose of identifying any significant changes in income qroup membership, it is necessary to combine the six income groups into three equivalent categories. (In this study, the 1970 dollar amounts were not converted to constant 1959 dollars). The following table contains the three equivalent income groupings: 


\section{$\underline{T A} \underline{B} \underline{E} \underline{E} I \underline{X}$}

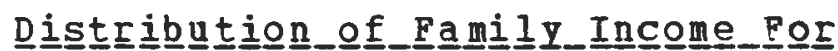

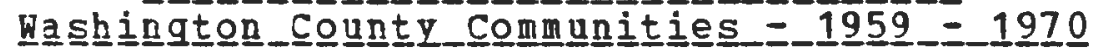

Yea돈

1959

1970

State 1970

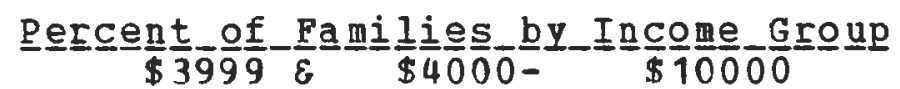

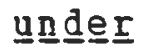

29.1

12.5

12.4
$\$ \frac{9}{6} \frac{9}{6} \frac{9}{6}$

40.7

39.5

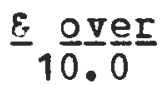

46.5

47.8

A significant change in the composition of member families in each of the redefined income categories from 1959 to 1970 can be seen. This change is characterized by a pronounced shift upward on the income scale. This shift indicates the apparent increase in affluence of the families in washington county and the state from the period of 1959 through 1970 .

Evident from the data in Table vIII is the county's relative position based on the lower three income groups. For the income groups $\$ 2,000$ and under, $\$ 2,000-\$ 3,999$, and $\$ 4,000$ - $\$ 6,999$, Washington County had 30.7 percent of its population within these categories. The State of Rhode Island had 28 percent of its total population falling into this range in 1970. While the difference between these two figures is not extreme, it nevertheless indicates a larger than average number of lower income residents in washington county. While the county experienced a dramatic upward movement in its income, it is evident that many individuals 
at the lower level of the income scale have not benefitted as much as other individuals.

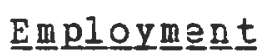

Total nonagricultural employment in Rhode Island grew from 232,704 jobs in 1960 to 301,073 in 1975, a gain of 68,369 jobs or a 29.3 percent increase.10 All regions of the state shared in this job growth except Providence County which experienced a -14 percent change in the 15 year period under review.

Washington county, which experienced a 102 percent increase (7445 jobs), was second to only Kent county in absolute and relative growth, 17,486 jobs and 110 percent, respectively. Table $x$ indicates the relative change in total employment in first, Washington county, and second, the remaining counties and the state, for the period of 1960 to 1975. 


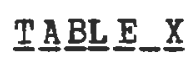

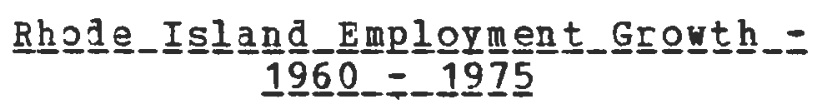

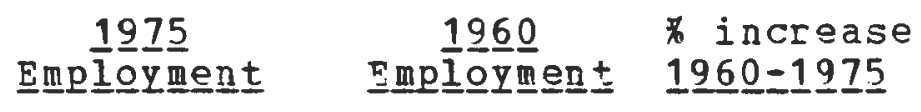

Charlestown

Exeter

Hopkinton

Narragansett

New Shoreham

North Kingstown

Richmon

South Kingstown

Westerly

Washington Co.

Bristol Co.

Kent Co.

Newport Co.

Providence co.

Rhode Island

250
151
697
861
130
4,932
780
2,864
4,076

$$
\begin{array}{r}
14.744 \\
9.029 \\
33.379 \\
11.936 \\
217.380
\end{array}
$$

301,073
57

8
391

273

35

1,179

888

1,030

3,438

7.299

7.865

15,893

7,765

189,123

232,704

29

Source: Fhode Island Department of Economic Development Basic Economic Statistics

브으ㄴㅡㅗㅗ픔

In 1970, a majority of the housing units in Rhode Island were single-family urits and owner occupied. In 1970 there were a total of 317,718 units of housing in the state. of these total units, 291,965 were counted as occupied during the census count. Table XI indicates the owner/I $\equiv$ ter split of the state's housing supply. 


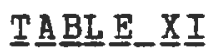

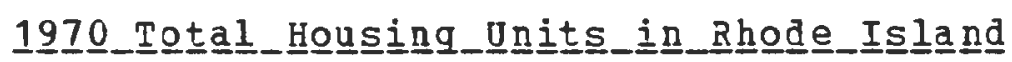

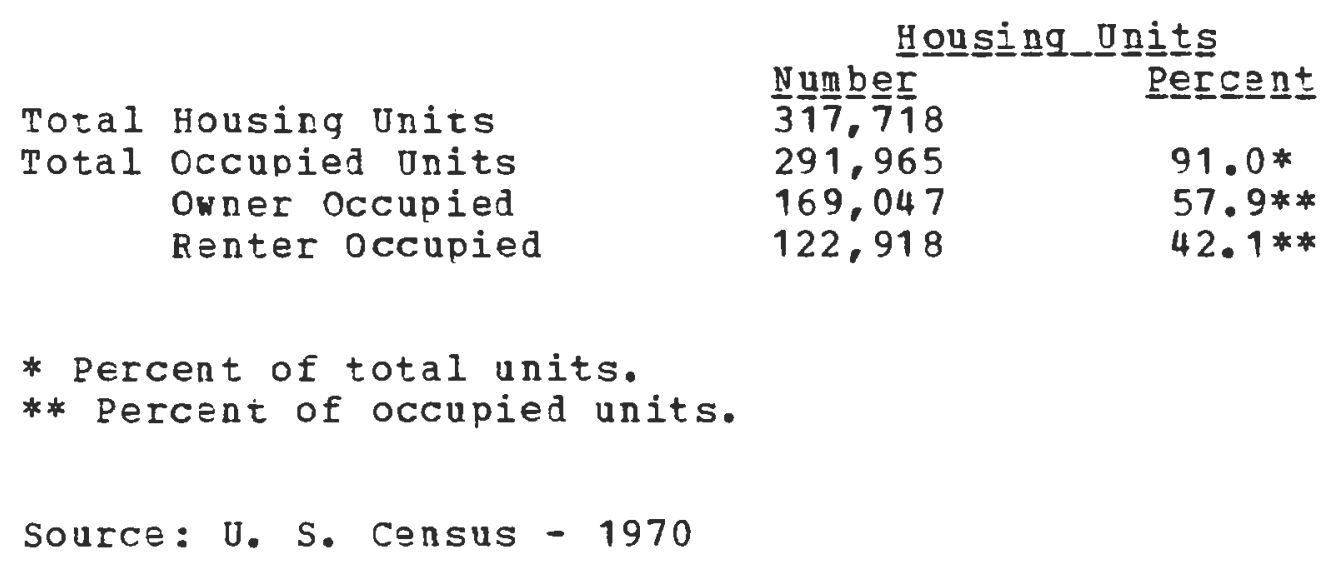

In 1970, for the state as a whole, the percent of the total housing units which were single-family units was 51.7. Another 18.4 percent were in two unit structures. No more the 29 percent were in structures of over two units and only. 7 percent were mobile homes.

The figures for washington County are somewhat different. Table XII identifies the owner/renter ratio of Hashington Countr's housing supply. 
TEABELEE_X

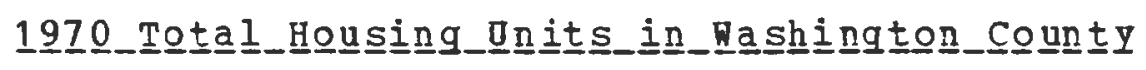

Total Housing Units

Total occupied units

owner occupied

Renter Occupied

\begin{tabular}{|c|c|}
\hline \multicolumn{2}{|c|}{ 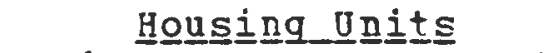 } \\
\hline$\frac{N}{3} \frac{\mathrm{u}}{0}, \frac{\mathrm{m}}{9} \frac{\mathrm{b}}{5} \frac{\mathrm{r}}{0}$ & Pe도ㄹㅛㅛt \\
\hline 24.432 & $78 *$ \\
\hline 14,558 & $59 * *$ \\
\hline 8,085 & $33 * *$ \\
\hline
\end{tabular}

Nㅡ므므므를

24,432

4,558
8,085

59**

* Percent of total units.

* Percert of occupied units.

Source: U. S. Census - 1970

The percent of Washingtor county's housing units which were single-family occupied was 70 percent. An aditional 12 percent were contained in two unit buildings. No morz thar 13 percent of the county's housing units were in structures containing more than two units, while 3 percent were mobile homes.

These trends continued through the period of 1970 1975 according to the data collected on new housing construation. The figures from this period indicate that 3,898 (79 percent) new units of single-family housing were authorized for construction in washington county, while 1,012 or 20 percent of the total of 4,910 authorized permits were for multi-family units.11 In that same period, a total of 29,704 units were authorized state wide, 15,124 for single-family units and 14,580 for multi-family 
units.12 These figures for the state represent an exceptionally well-balanced rate of residential development (50 perzent single-family and 49 percent multi-family). Information on mobile homes, contained in Table XIII, suggests that for the most part communities in hashington County do not depend on mobile homes to provide housing in any significant amounts. One exception to this is the rown of Exeter, with 25 percent of its total housing units contained in mobile homes.

With mobile homes making up less than 1 percent of the State's residential units, and 2.4 percent of the county's total housing units, it is surprising to note that in Exter, mobile homes comprised 25 percent of the total number of units. 


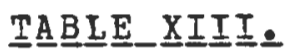

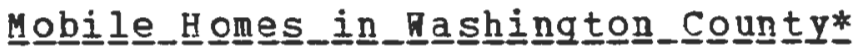

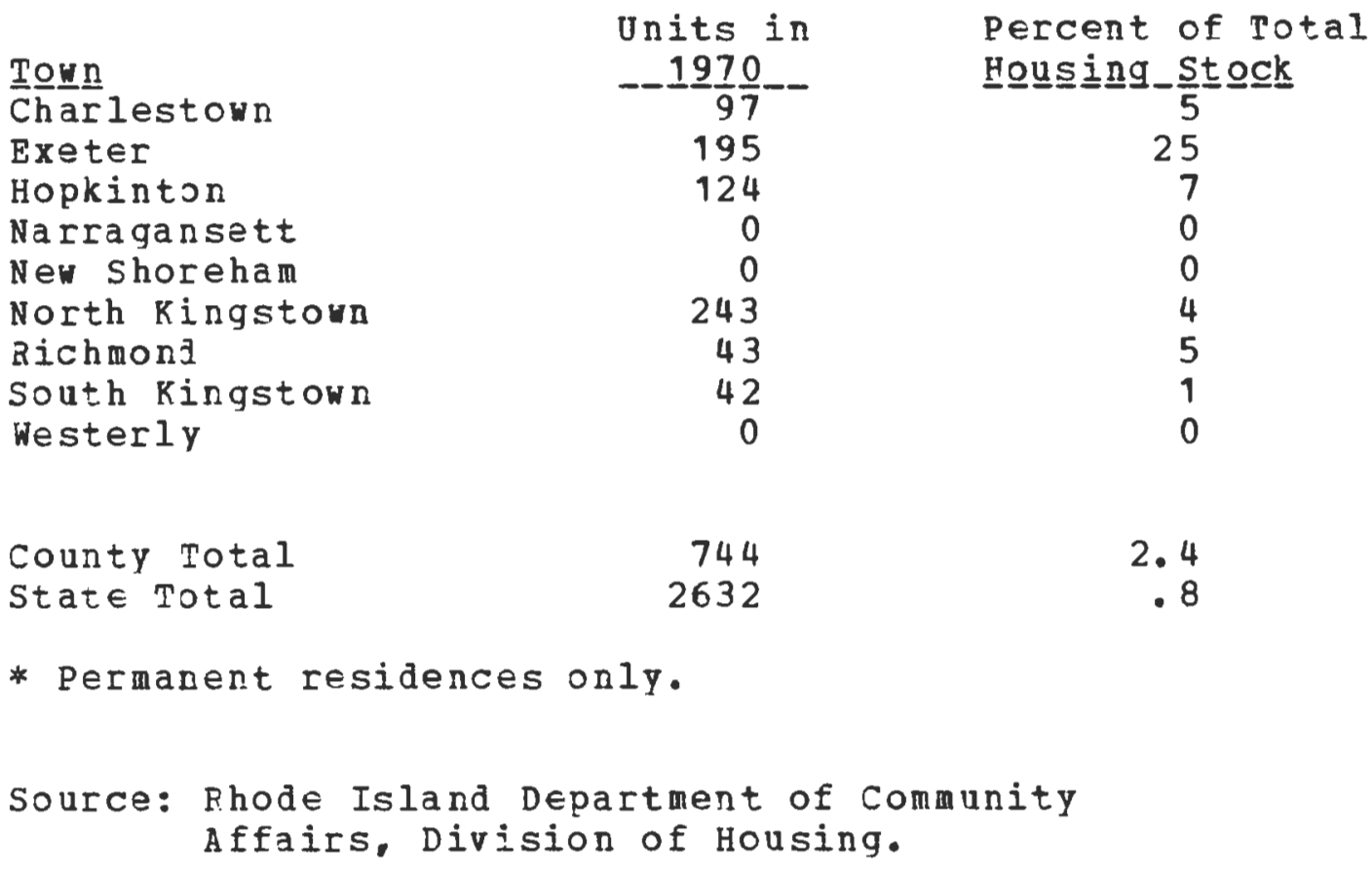

In analyzing the data on trends in population qrowth, income, employment, and housing in Rhode Island and Washington County, some bright spots can be identified. The absolute number of jobs and housing units have risen in both the state and Mashington County. A family's median income has also increased in both these jurisdictions.

The information pertaining to families with incone below the poverty level indicates that compared to the State of Rhode Island, Washington county contains its appropriate share of these families.

While the data related to employment, housing units, 
median family income, low-income families, and female headed households may in some cases be somewhat dated. I jo believe that the realized growth and balance of the previously mentioned elements can be verified from additional sources.

What is bothersome at this point is that whatever position of equality washington county may have enjoyed vis-a-vis the state in the early 1970s, it may have boen lost by the time of this investigation. While the state as a whole provided for a variety of housing types to its residents from 1970 to 1975. Washington County allowed predominately single-family units only to be built. This type of construction in washington county can do little to alleviate the underrepresentation of minority individuals identified in 1970, and will lead to future underrepresentation of families at the lower end of the income scale. While most communities in the state provided increased opportunities for individuals to choose from a variety of housing options, the Hashington county towns acted to restrict even further their housing choices.

This condition is more pronounced when the previously identified growth in employment is considered. Without the provision of low cost housing. many individuals can not take advantage of the growing job market. Washington county has done very little to increase the number of available rental units for both low-income and more affluert individuals. 
The conclusions drawn from this investigation of social characteristics appear to identify Hashington count $y$ as an area which has undergone significart growth in the past decade. This growth includes population; emplovment; median income, although somewhat below that of the state; and total housing units. While such growth in and of itself is not negative, one must also consider the persons not benefitting from these increases.

It appears that housing opportunities for individuals seeking multi-family homes and mobile home units have not increased. This absence of housing choice will tend to bar the introduction of new low-income and minority individuals into the county. While the county did experience a great rise in family incomes, the data might suggest that not all families have benefitted equally.

The rise in family incomes, employment opportunities, population, and total single-family housing units all point to one conclusion. During the last two decades the growth in Mashington county appears to have increasingly favored the more affluent of Rhode Island's citizens. While this conclusion seems to be resonable, it is the purpose of this investiqation to identify the role of zoning in the possible exclusion of minority individuals. It will be only after the zoning ordinance analysis that any conclusions can be drawn which might identify the role of municipalities in restricting the availability of housing choice. 
At this point of the study it is fair to state only that the general "vell being" of the Hashington county residents has been increased, and it appears that not all of the residents have benefitted from this economic growth. Also, an increasing percentage of the new and existing housing supply appears to be directed at the single-family, owner occupied buyer, not the rerter. 


\section{F으모N으로토}

1. Based on Rhode Island Department of Economic Development projections of the 1975 population.

2. United States Bureau of the census,

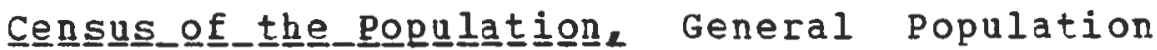
Characteristics, Rhode Island 1960.

3. Orited States Bureau of the census,

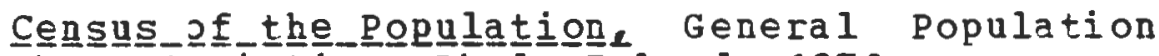
Characteristics, Rhode Island, 1970.

4. I므르.

5. I미므.

6. I므르.

7. I므르.

8. I므르.

9. Rhode Island Department of Economic Development,

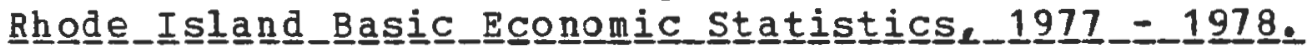

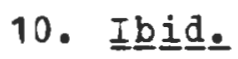

11. Rhode Island Department of Community Affairs, "Selected Housing Stock Information in Rhode Island by Market Area, City and Town," 1975.

12. $\underline{\underline{I}} \underline{\underline{i}} \underline{\underline{d}}$. 
V. ZONING ORDINANCE ANALYSIS 
The purpose of this section is to identify the prevaleace in washington county of governmental zoning requlations that prevent the construction of housing at a cost affordable by low- and moderate-income residents. Ihe severity and pervasiveness of these regulations may impose sufficient costs on the construction of residential units to make more difficult the acquisition of new housing, even by middle-income households.

Virtually all regulations affect the cost of constructing a housing unit. However, reasonable judgments can be made that identify if regulations are present that allow for the construction of types of dwelling units that are most likely to reach the housing needs of low- and moderate-income households.

Housing costs are rising rapidly today because of a variety of factors. Many are not related to land-use regulations and will affect the cost of housing regardless of the regulations developed to guide housing construction. Nonetheless, there is agreement that land-use regulations can be a contributing factor to the increase in housing costs. More important, is the fact that unless there are widely available subsidies allowing low- and moderateincome householls to benefit from the increased housing supply, restrictive land-use regulations will continue to jeopardize the mechanisms created to reduce the cost of housing. These conditions are particularly critical where there is a demand for housing in locations not containing 
an adequate supply of housing at costs affordable to lower income households.

Certain difficulties in determining whether zoning provisions do or do not have an exclusionary impact should be observed. First, zoning by itself does rot construct housing. The need is to provide a balance of housing types for a IEpresentational population. The provision of housing for low- and moderate-income individuals should become an integral part of every municipality's planning efforts.

In communities which have grown in the past decades but which have failed to accommodate the lower income earners, the task of creating a community that provides housing for all sectors of the population requires positive action to see that it is accomplished.

secord, many conditions in the housing market, including zoning, operate to reduce housing opportunities for families of low- and moderate-incomes. In fact, it is difficult to isolate zoning's causal effect from others. However, it is not difficult to indicate that some zoning provisions have the effect of adding to the cost of housing.

Third, many zoning regulations, while having the effect of increasing housing costs and excluding low- and moderate-income households, have other legitimate purposes as well. It is necessary to understand how such purposes can be served without the detrimental effect of restricting 
opportunities for all Rhode Island individuals.

The zoning ordinance analysis was conducted from the available zoning ordinances of the towns in pashington County. The analysis is designed to provide a general impression of the existence of zoning practices that most directly affect the ability to construct lower cost housing and that could be interpreted as fairly and directly as possible with the most up-to-date information available. The analysis focused on the treatment of residential units in the ordinance rather than other types of construction'or land-use.

The following elements were identified in Chapter II, Table II, as the most appropriate way of indicating the extent to which a zoning ordinance may escalate the cost of housing. Also, the prohibition of residential forms of housing have also been iden+ified. From this list contained in Table II, the following coded version will be utilizel in this section of the investigation: 


\section{$\underline{\underline{T}} \underline{A} \underline{B} \underline{E} \underline{E}-\underline{X} \underline{I} \underline{V}$}

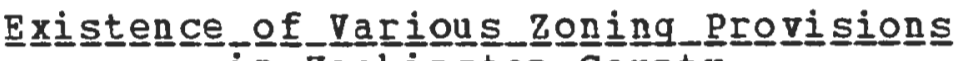 \\ in}

\section{Coodeㄹ}

(1) Single-family, minimum lot size of 20,000 sq. ft. or nore.

(2) Single-family, minimum floor area of $1,000 \mathrm{sq}$. ft.

(3) Yulti-family prohibited.

(4) Multi-family only by special requirements.

(5) Multi-family, minimum density less than 5 dwelling units per acre or more than $8,000 \mathrm{sq}$. ft. per welling unit.

(6) Iulti-family allowed but limited by bedroom restrictions.

(7) yobile homes prohibited.

(8) Single-family, minimum lot size of $8,000 \mathrm{sq}$. ft. or less.

(9) Multi-family permitted as of right at 6 dwelling units or more per acre without bedroom restrictions.

(10) Mobile homes permitted

The issue of allowing the construction of multi-family units as of right or through special provisions requires some attention. It is not necessarily true that because a jurisdiction allows multi-family units only through some special review mechanism that it presumptively restricts those residential types. Nonetheless, such mechanisms are often used for the purpose of restricting multi-family development and the refore must be riewed in that light.

The following guidelines and definitions were used in the zoning ordinance analysis:

Multi-family units were considered to be structures 
of more than two household dwelling units. Thus, single-family and two-family units were classified similarly and if a zoning ordinance only permitted single-family and two-family units, it was considered to exclude multi-family structures.

In all instances the most inclusionary standard was chosen, even if only restricted use was practicel. For example, if $7,500 \mathrm{sq}$. ft. lots were permitted hut very little land in the town was zoned to permit them, the smaller size was still noted as being permitted in a town. or, if the smallest lot size was permissible only with water and/or sewer facilities, it was still listed as the minimum lot size.

Where mobile homes were not mentioned in the ordinance, they were considered to be prohibited. Also, mobile homes were considered permitted uses only when they were allowed for permanent residence.

Beàrcom restrictions include a limit on the number or proportion of units that contain a specified number of bedrooms, e.q. no more than 20 percent of the units with 2 bedrooms, or a limit on the number of bedrooms permitted in units.

The following analysis is based on the criteria identified above, incorporating the principles outlined in Thapter II. Each of the nine rashington county communities 
will be addressed separately for this analysis. After all of the municipalities have been reviewed, a statement can be made as to the overall county zoning performance. The results of the zoning analysis are displayed in Tables XV and XVI.

\section{$\underline{T} \underline{A} \underline{B} \underline{E} \underline{E}-\underline{X} \underline{V}$}

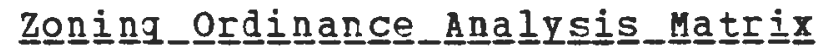

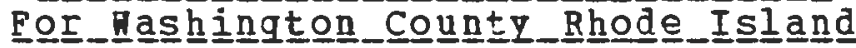

TOWN

Char lestown 1 Exeter 2 Hopkintor ${ }^{3}$ Na rragan sett 4 New Shoreham 5 North Kingstown6 Richmord 7 South Kingstown Hesterlyo

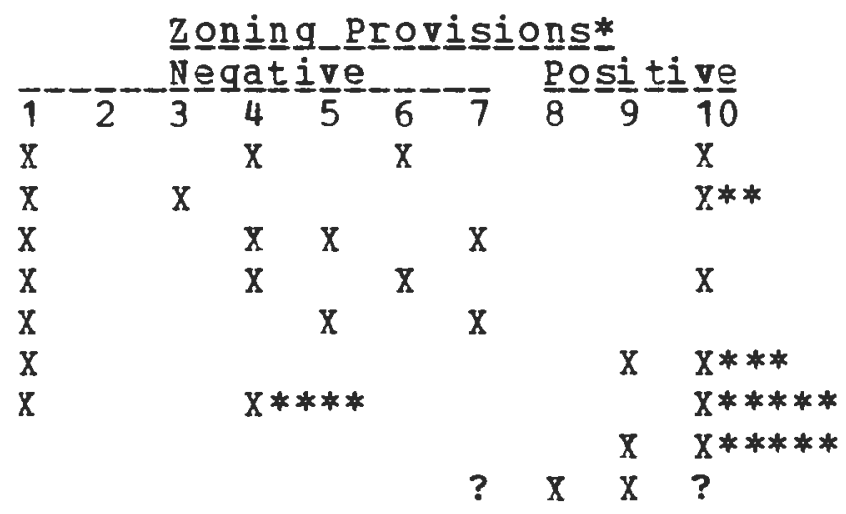

\footnotetext{
* See zoning provision code, Table XIV. * Special requirements. ** 5 acre minimum lot or trailer park. *** Only conversions of existing structures. Must have historic significance or be on National pegister of Historic places.

*** * only in existing trailer parks.

? Depends on ruling of zoning Inspector.
} 


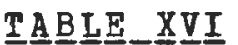

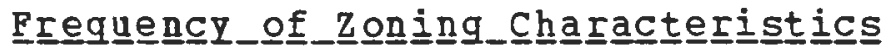

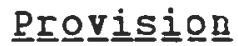

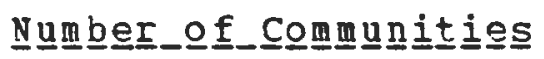

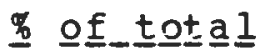

(1) Min. S. F. lot size $20,000 \mathrm{sq}$. ft. +

(2) Min. S. F. floor area size $1,000 \mathrm{sq}$. ft. +

00.0

(3) Multi-family prohibited 1

(4) Multi-family, special reguirements

(5) Multi-family at densities below 5 du/acre

(6) Bedroom restrictions

(7) Mobile homes prohibited 2

22.2

(8) Min. S. F. lot size $8,000 \mathrm{sq}$. ft. or less 1

(9) Multi-family permitted as of right

(10) Mobile homes permitted 6

11. 1

33.3

66.6

There has been no attempt to establish a hierarchy of most to least restrictive jurisdictions in Nashington County. Aditionally, no attempt was made to provide a definitive ranking which would identify restrictiveness by some cutoff point. Rather, the analysis in Table XV and XVI is an attempt to identify the extent to which, and the manner in which commuties in Vashington county rastrict the possibility of constructing lower cost housing.

In reviewing the outcome of the zoning ordinance analysis, one must look both at the individual results of each zoning provision and at combinations of zoning provisions. 
Most significant of all the zoning provisions studied is the prohibition of small lots. seven out of nine communities in washington county require that single-family residential units be constructed on at least a 20,000 square foot lot (one-quarter acre). The most widely used explanation as to the validity of this requirement concerns the preservation of a community's "rural character."

mo compound the effect of this large-lot requirement, five out of the nine communities either prohibited multi-family construction totally, e.g., Exeter, or delineated special requirements to be accomplished before construction could be approved. The range of minimum lot sizes went from 6,000 square feet in Hesterly to 160,000 square feet (four acres) in New Shoreham. Between these two extremes ranged minimum lot sizes of $20,000,40,000$, 60,000 , and 80,000 square feet. In one ordinance, discussed later, a commity required a five-acre minimum lot size for use by individual mobile homes.

Two communities, Hopkinton and New Shoreham, totally prohibited mobile homes, while westerly required a ruling to be made by the zoning Inspector as to the merits of a particular request. on the other hand, six communities allowed mobile homes although with either the provision of a special requirement process or of the mobile home being placed in an existing trailer park. North kingstown went one step further and required mobile homes to be placed in a trailer park or on a five-acre lot! This exaction is 
highly exclusionary because within the same zone in which a mobile home can be located only on a five-acre lot, a single-family dwelling can be constructed on two-acre lots. What possible health or economic gains can be realized by requiring that the mobile home owner buy three additional acres beyond the two acre minimum lot size already in existence? clearly this can not be rationally defended by the town.

other items of interest in the review of the zoning regulations include the lack of a minimum floor area requirement for single-family dwellings. other studies have identified this provision as one of a few widely employed techniques used in controlling urban growth. 10 Also, the use of bedroom restrictions in multi-family units as a limit on development was found in only two of the county's nine communities.

This analysis would not be complete unless trends identified for some of the communities and rashington County in sum vere not discussed.

The review process has identified the Town of Exeter as one in which the construction of low cost housing is severely limited. Exeter requires large-lot construction, prohibits multi-family units, and provides for a special requirement process for mobile homes.

Besides the large building lot requirements, the 
Towns of Hopkinton and New Shoreham totally prohibit mobile homes. These two communities also provide that any multi-family construction will be of low density design.

The most inclusive communties in Washington county appear to be South Kingstown, resterly, and possibly North Kingstown. South Kingstown and mesterly were the only jurisdictions which did not require large-lot development and, at the same time, permitted multi-family units as of right. North Kingstown also allowed multi-family structures as of right but did require larger minimum buildirg sites.

The remaining commities tend to fall somewhere between the categories of most exclusive and inclusive discussed above.

As for Washington County in general, the distinction is not as simple. The most obvious conclusions to be gained from this investigation revolve around three different types of residential construction. First. Washington county relies heavily on the large-lot requirement to influence its single-family building patterns. Second, while mobile homes have not been totally banned in most communties, there placement has been strictly limited by special requirements and confinement to existing trailer parks only. Lastly, multi-family units have been prohibited or restricted by several means in $a 11$ but three comunities.

conclusions based upon this analysis tend to point to 
the general exclusive nature of the jurisdictions examined. It is evident that the county could, and should, improve its zoning practices to provide for a greater variety of housing. Currently, it appears that the excessive minimum lot requirements are the single provision which must be addressed to allow for increased single-family construction affordable to lower income residents. In an highly rural county, lacking extensive public water and sewer facilities, this provision appears to be the most effective in excluding low-income residents. 


\section{FOOOT $\underline{\text { NOOTES }}$}

1. Town of Charlestown, Rhode Island,

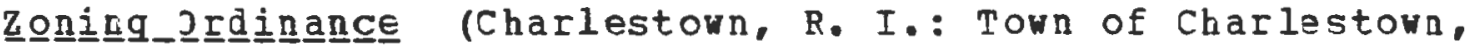
Ju1Y 8, 1974).

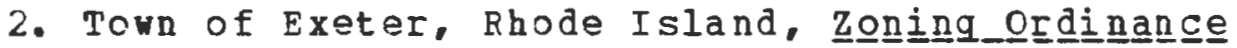

(Exeter, R. I.: Town of Exeter, May 2, 1977).

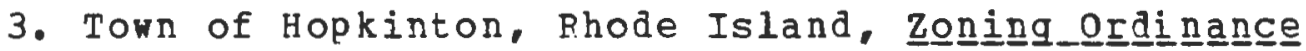
(Hopkirton, R. I.: Town of Hopkinton, March 23,1971 ).

4. Town of Narragansett, Rhode Island,

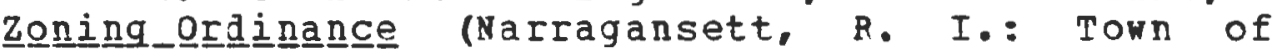
Narragansett, revised June 28, 1977).

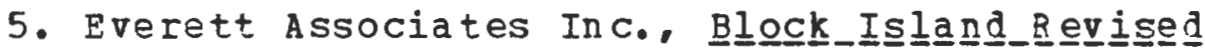

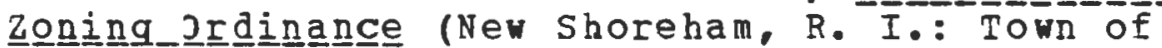
NEW Shoreham, 1977).

6. Town of North Kingstown, Rhode Island,

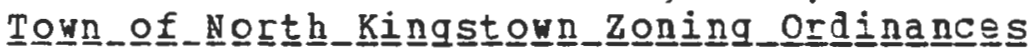

(North Kingstown, R. I.: Town of North Kingstown, April $8,1974)$.

7. Town of Richmond, Rhode Island, Zonning_ordinance (Richmond, R. I.: Town of Richmond, March 26,1970 , amended January, 1978).

8. Town of South Kingstown, Rhode Island,

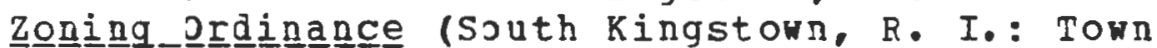
of South Kirgstown, March 29, 1976).

9. Town of Westerly, Rhode Island, Zoning (Westerly, R. I.: Town of nesterly, July 19, 1962).

10. Lynne B. Sagalyn, and George Sternlieb,

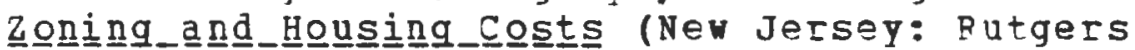
University, 19721. 
VI. SUMMARY 
This final section brings together some of the evidence about the social characteristics of washington County with the data about the zoning regulations. It must be restated here that zoning is but one of many factors affecting commuity growth and composition. It may have a strong bearing on the character of a town but its role is only contributory. As pointed out at the outset of this study, findings of a close correlation between the severity of zoning restrictions and the social characteristics of a community can, and should, give rise to investigation in greater depth of the factors at work in a town. Such a finding from the data presented in this report would be insufficient to permit a conclusion to be drawn as to whether a town's zoning practices vere unfairly responsible for the total exclusion of portions of the population.

For the purpose of comparing the zoning data and the social characteristic information, a sumary of the pertinent social conditions in Mashington county was prepared (Chapter IV). This set of data was compared with the data presented in the section describing the communities zoning practices (Chapter v).

The analysis of the zoning patterns of the towns suggested a tri-part division. The first group of towns contained those with the most severe zoning restrictions, i.e., prohibitions against small lots, multi-family housing, and mobile homes. Within this category were the towns of Exeter, Hopkinton and New Shoreham. 
Another group of towns consists of those with the least severe zoning practices and is comprised of south Kingstown, Westerly and possibly North Kingstown. These towns have been included in this grouping because they tend to be more open than most communities in Hashington county to the inclusion of households of low- and moderateincomes.

The remaining group of towns, Charlestown, Narragansett, and Richmond contain zoning practices that are less well defined.

When the information obtained in the zoning ordinance analysis was reviewed vis-a-vis the social characteristic data, several interesting points were highlighted.

All of the communities identified as belonging to the most restrictive grouging, as well as Richmond, also were among the lowest in Washington County in terms of median family income in 1959 and 1969. Families identified in this income grouping must certainly find the availability of housing at affordable costs restricted even in their own communities.

Another factor which tends to restrict the availability of low-cost housing in washington County is the general lack of rental units. Washington County is largely dominated by dwelling units of the single-family, owner occupied category. Also, of the new units under construction as estimated by the review of the building permits awarded, almost 80 percent were expected to be 
single-family units for the period of 1970 through 1975.

The review of housing information also identified that a great deal of the county's housing supply, 22 percent, could not be regarded as year-round residences. It is feared that a great many of these sumer homes and cottages have been inadequately vinterized to accommodate the increased demand for year-round residences in this area. This is particularly true in and around the Oniversity of Rhode Island campus, as students have bid up the cost ard tightened the supply of housing.

Also identified in chapter IV was the underrepresentation of minority population individuals in Washington county. With the ircreases in housing costs and the predominately single-family dwelling units being constructed at this time, it appears that the private housing market can not or will not allow greater numbers of minority families to locate in the area. The public sector will have to become more involved in the housing market to foster any positive changes in policy.

It is this author's view that many towns in Hashington county practice forms of zoning that have had the probable effect of excluding large portions of the State's population from residence within the boundaries of those jurisdictions. Further, the data on social characteristics indicates that whether or not the 
communities intended to exclude minorities or low-income and moderate-income households, those groups do not live in great numbers in those communities.

It cannot be said with certainty that it is only the zoning actions of these communities that have excluded minorities, the poor, and moderate-income households, for many other factors may have played a part. Ne can be certain, however, that the omission to make inclusion possible can be identified as a cause for the failure of so many of these towns to have a fair balance of the racial and income groups of Rhode Island.

It may be the case that by combining the restrictive zoning practices with the inaction regarding pablicly assistej housing for multi-family units, towns have established a situation in which lower priced housing is generally not available.

What emerges from this study of the social, economic, and civil rights inpact of the town' zoning practices is that the state of Rhode Island, by its zoning enabling legislatior, has made possible the practices which, together with aditional public and private acts, increase the deqree of separation between higher and lower income groups and between whites and members of racial or ethnic minorities.

B failing to counter the aggregate consequences of local zoning to exclude multi-family housing, small building lots and mobile homes, the state quietly tolerates 
these actions which make the achievement of equal housirg opportunities increasingly difficult to attain.

The extensive use of large-lot requirements has resulte in more expensive building sites for individuals wishing to obtain housing in Washington County. This requirement has not had the effect desired by many municipal officials. Instead of preserving the rural character of the county, large-lot development has actually destroyed most of the remaining colonial reminders to the past by promotirg sprawl.

The continued use of this land-use technique will foster increased sprawl, not the anticipated preservation of the county's remaining rural character as so many have stated. 
Selected Bibliography

Amanullah, Syed. "Mobile Homes on Individual Lots:

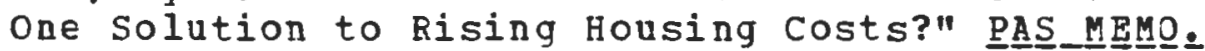
Chicago. Il.: American Society of Planning Officials, 1977 .

American Bar Association. "Housing for All Under Law." Cambridge, Mass.: Ballinger Publishing, 1977.

Babcock, Richard. "On the Choice of Forum." 27 Land Use Law and Zoning Digest. Chicago, Ill.: American Society of Planning officials, 1975.

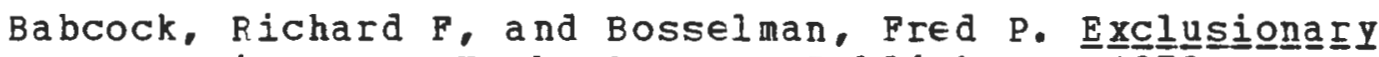
Zoning. New York: Praeger Publishers, 1973 .

Bassett, Edward M. Zonging. New York: Russel Sage Foundation, 1940 .

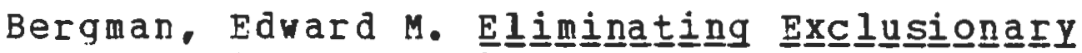
Zonㅡㄹㅗ. Cambridge, Mass.: Ballinger Publishing Company, 1974.

Brower, David J., Owens, David H, Rosenberg, Ronald, Botuinick, Ira, Mandel, Michael. U드ㅁㅡㅡㅡ G프uㅡhㅡ

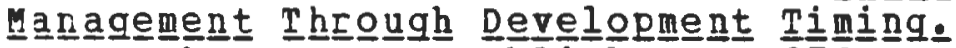
New York: Praeger Publishers, 1976.

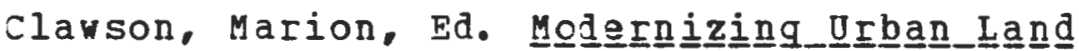
Pollícy. Baltimore, Maryland: Johns Hopkins University Press, 1973.

Connecticut Commission on Human Rights and opportunities.

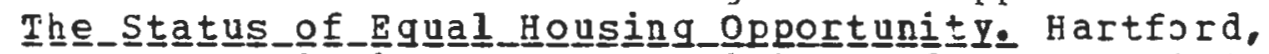
Conn.: Commission on Human Rights and Opportunities. 1978.

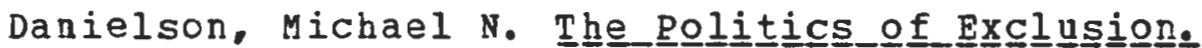
New York: Columbia University Press, 1976. 


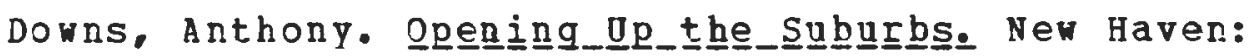
Yale university Press, 1973 .

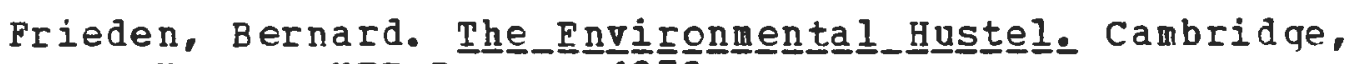
Mass.: MIT Press, 1979 .

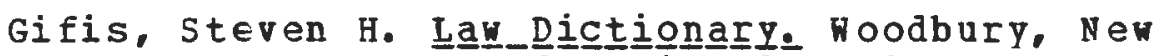
York: Barrons Educational Series, Inc., 1975.

Linowes, Robert R., and Allensworth, Don T. The

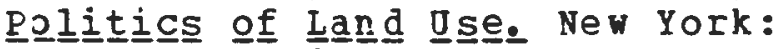
Praeger publishers, 1973.

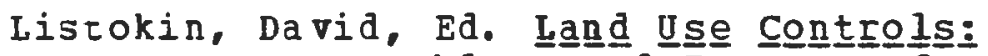

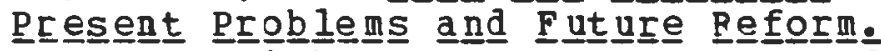
Ne Brunswick, New Jersey: Center for Urban Pol icy REsearch, 1974 .

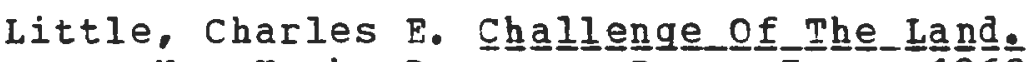
New York: Pergamon Press Inc.. 1969

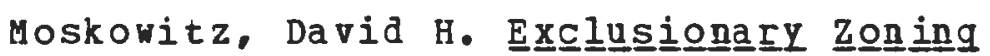
Litiqatílon. Cambridge, Mass.: Ballinger Publishing CompanY, 1977.

National Comission on Urban Problems. Building the

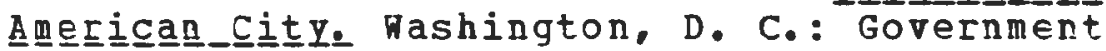
Printing office, 1968.

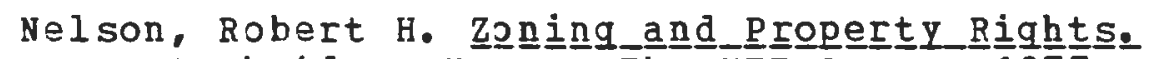
Cambidge, Mass.: The MIT PIess, 1977.

Perin, constance. Evergythhing in itts placㅡ․ Erinceton, New Jersey: Princeton oniversity Press, 1977.

Quinn, James C. "Challenging Exclusionary Zoning: Contrasting Recent Federal and State Court Approaches." Pordham Urban Law Journal. New York, $\mathrm{N} \equiv \mathrm{W}$ York: Fordham University. 1975.

Rhode Island Department of commity Affairs. 
"Selected Housing Stock Information in Rhode Island by Market Area, City and Town."

Providence, R. I.: Department of Community Affairs, 1975.

Rhode Island Department of Community Affairs. Division of Housing and Governmental services, Housing Assistance Section. "Selected Information on Mobile Homes in Rhode Island." Providence, R. I.: Department of Community Affairs, 1974.

Rhode Island Department of Economic Development.

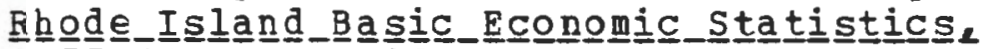
$1 \underline{9} \underline{7}=19 \underline{7}$ … Providence, R. I.: Department of Economic Development, 1978.

Rhode Island Statewide Planning Program. "Population and Economic Projections,"

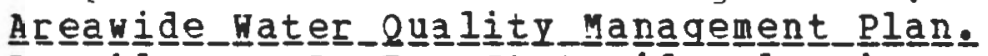
Providence, R. I.: Statewide Planning Program, 1977.

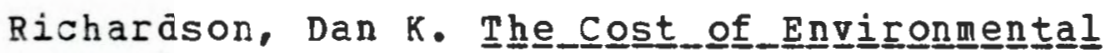

트으트드으으. New Brunswick, New Jersey:

Certer For Urban Policy Research, 1976.

Sagalyn, Lynne B., and Sternlieb, George. zonning

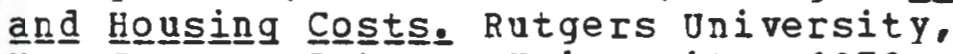
New Jersey: Rutgers University, 1972.

Schnidman, Frank. "New York Trail Court Takes Away Municipalities' Presumption of Legislative Validity." U드므므_Laㅡㅁㅡ. Vol. 37. No.5, Hashington, D. C.: Ürban Land, 1978.

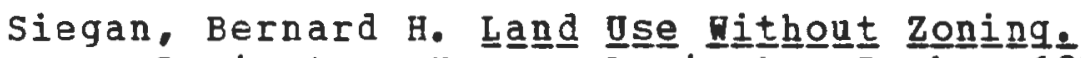
Laxington, Mass.: Lexington Books, 1972.

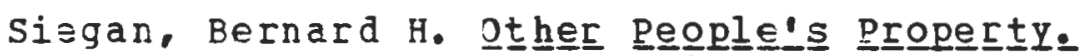
Laxington, Mass.: Lexington Books, 1976.

Strom, Fredric A. "current Trends in Mobile Home Zoning."

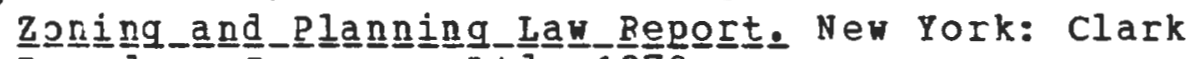
Boardman Company, Ltd, 1978. 
Town of Charlestown, Rhode Island.

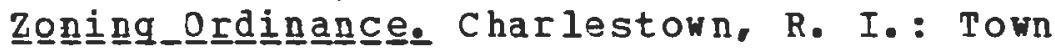
of Charlestown, 1974.

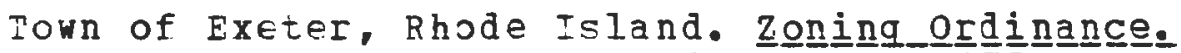
Exeter, R. I.: Town of Exeter, 1977 .

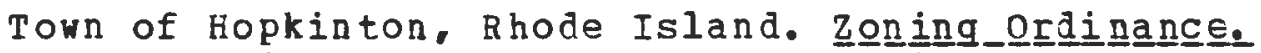
Hopkinton, R. I.: Town of Hopkinton, 1971.

Town of Narragansett, Rhode Island.

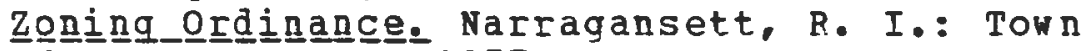
of Narragansett, 1977.

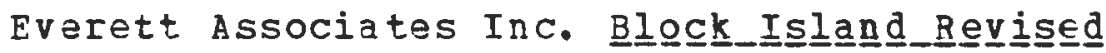

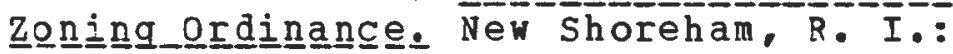
Town of New Shoream, 1977.

Town of North Kingstown, Rhode Island.

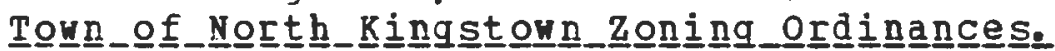
North Kingstown, R. I.: Town of North Kingstown, 1974.

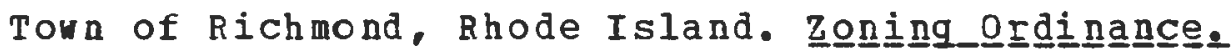
Richmond, R. I.: I own of Richmond, 1978 .

Town of South Kingstown, Rhode Island.

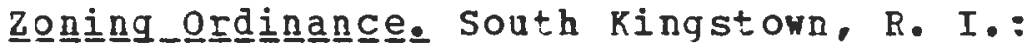
Town of South Kingstown, 1976.

Town of Westerly. Zoning P. I.: Town of hesterly, 1962.

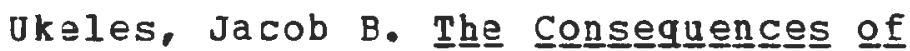
Munnicipal zonging. Washington, D. C.: Orban Land Institute, 1964.

United States Bureau of the Census.

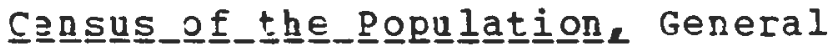
Population Characteristics, Rhode Island. Washington, D. C.: U. S. Government Printing office, 1961 and 1971. 
Nilliams, Norman. "Planning Law and the supreme Court."

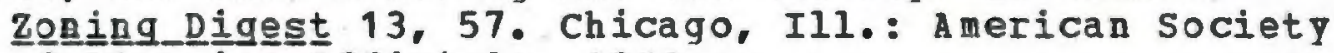
of Planning officials, 1961. 